\title{
Inventory of the Rio Grande Missions: 1772 San Juan Bautista and San Bernardo
}

Felix D. Almaraz Jr.

Center for Archaeological Research

Follow this and additional works at: https://scholarworks.sfasu.edu/ita

Part of the American Material Culture Commons, Archaeological Anthropology Commons, Environmental Studies Commons, Other American Studies Commons, Other Arts and Humanities Commons, Other History of Art, Architecture, and Archaeology Commons, and the United States History Commons

Tell us how this article helped you.

This Article is brought to you for free and open access by the Center for Regional Heritage Research at SFA ScholarWorks. It has been accepted for inclusion in Index of Texas Archaeology: Open Access Gray Literature from the Lone Star State by an authorized editor of SFA ScholarWorks. For more information, please contact cdsscholarworks@sfasu.edu. 


\section{Inventory of the Rio Grande Missions: 1772 San Juan Bautista and San Bernardo Creative Commons License \\ (c) (1) (9)}

This work is licensed under a Creative Commons Attribution-NonCommercial 4.0 International License 


\title{
INVENTORY OF THE RIO GRANDE MISSIONS: 1772 SAN JUAN BAUTISTA AND SAN BERNARDO
}

\author{
Translated and Edited
}

by

Félix D. Almaráz, Jr.

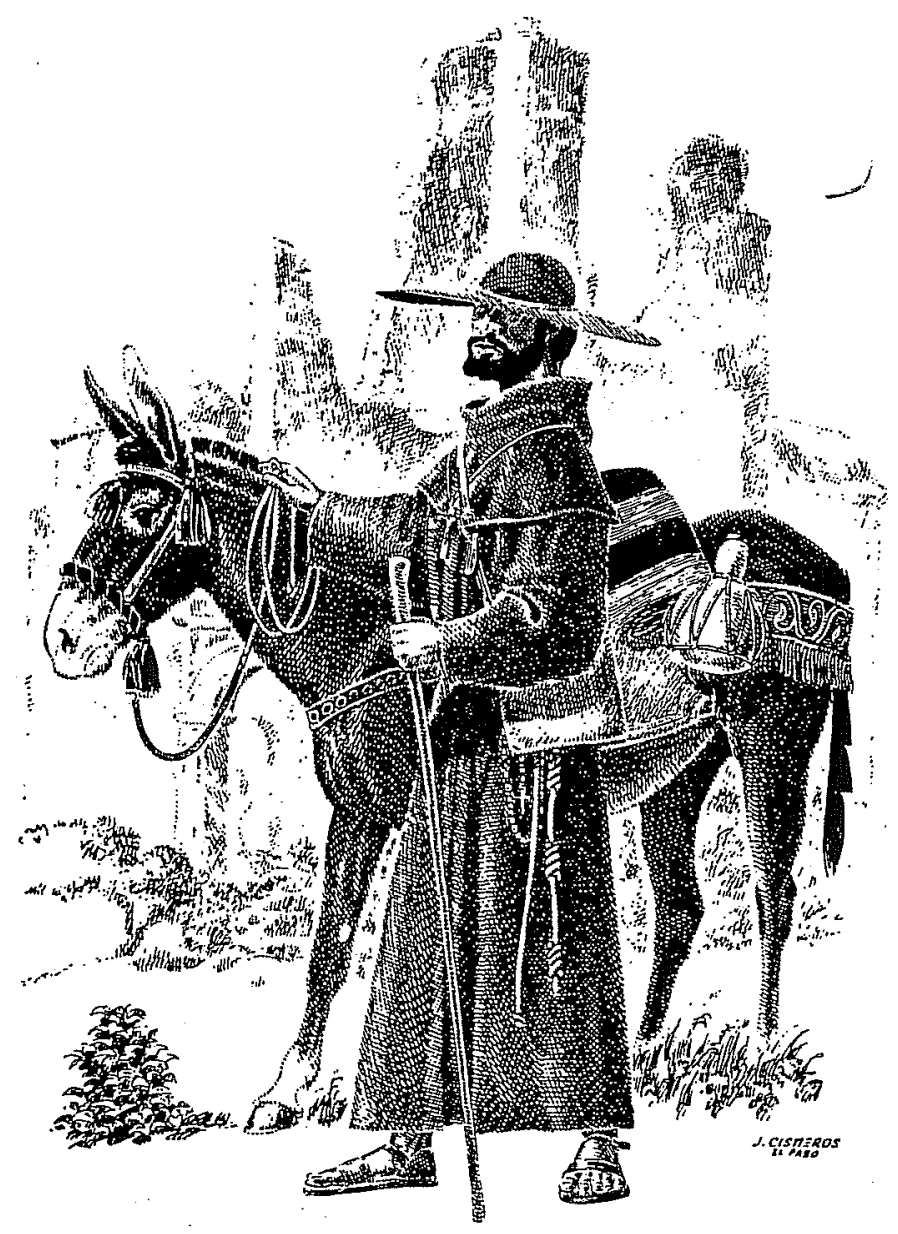

Center for Archaeological Research

The University of Texas at San Antonio Archaeology and History of the San Juan Bautista Mission Area, Coahuila and Texas

Report No. 2 


\author{
Center for Archaeological Research \\ The University of Texas at San Antonio \\ 78285
}

Thomas R. Hester, Director

Archaeology and History of the San Juan

Bautista Mission Area, Coahuila and Texas

This series of publications presents information gathered from archaeological investigations and historical research at the Spanish mission complex in the area of Guerrero, Coahuila, Mexico. Additional volumes are forthcoming.

No. 1 (1979) Crossroad of Empire: The Church and State on the Rio Grande Frontier of Coahuila and Texas, 1700-1821. By Felix D. Almaraz, Jr. $\$ 5.00+.28$ tax for Texas residents.

No. 2 (1980) Inventory of the Rio Grande Missions: 1772; San Juan Bautista and San Bernardo. Translated and edited by Felix D. Almaraz, Jr. $\$ 5.00+.28$ tax for Texas residents.

No. 3 (1979) Ethnohistoric Notes on Indian Groups Associated with Three Spanish Missions at Guerrero, Coahuila. By T. N. Campbe11. $\$ 4.00+.22$ tax for Texas residents. 
INVENTORY OF THE RIO GRANDE MISSIONS: 1772

SAN JUAN BAUTISTA

AND

SAN BERNARDO

Translated and Edited

by

Félix D. Almaráz, Jr.

Center for Archaeological Research The University of Texas at San Antonio Archaeology and History of the San Juan Bautista Mission Area, Coahuila and Texas

Report No. 2 
Preface ......................

Acknowledgments .................... . . $i$. . . . . .

Introduction ...................... 1

Inventory of Mission San Juan Bautista

of the Rio Grande del Norte . . . . . . . . . . . . . . 2

Church .................... 3

Living Quarters in the Convent .............. 13

Indian Puebto . . . . . . . . . . . . . 14

Mission Ranch ................. 15

Alhajas, Tools, Provisions and Effects
within the Mission . . . . . . . . . . . . 15

Archive ................... 16

Assets of the field . . . . . . . . . . . . . 27

Census of Conjugal Families and Tribal Groups Who Actually Reside in this Mission ... . . . . . . . . 28

Testimony of the Formal Transfer of Mission San Bernardo

of the Rio Grande del Norte to the Reverend Fathers of the

Sacred Province of Jalisco, Year of 1772 . . . . . . . . . 35

Church .................... 35

Books of Administration .............. . . 44

Assets of the Mission .............. . . 45

Convent ..................... . . . 48

Account Books .................. 56

Census ..................... 56

Notes ........................ 64 
This monograph is the second in the series of data-oriented reports resulting from the archaeological and ethnohistorical investigations centered on the Spanish mission complex near the modern town of Guerrero, Coahuila, Mexico. Dr. Félix D. Almaraz of The University of Texas at San Antonio has now prepared two of the volumes in the series, of which this is the second. His translation of the 1772 mission inventories of San Juan Bautista and San Bernardo should be of considerable value to those interested in the Spanish Colonial history of northern Mexico and Texas.

The Gateway Project was supported in large part by the National Endowment for the Humanities (Grant No. R0-21425-75-408). Additional funding was generously provided by the Kathryn Stoner $\mathrm{O}^{\prime}$ Connor Foundation and the Sid Richardson Foundation. Research was carried out in Mexico under terms of a permit from the Instituto de Antropología e Historia. We are grateful for the opportunities and aid provided by all concerned.

R. E. W. Adams

May 1980 


\section{ACKNOWLEDGMENTS}

Indicative of the commitment to the concept of interdisciplinary study at The University of Texas at San Antonio, the Center for Archaeological Research in 1975 invited me to conduct investigations in regional, national and foreign archives for documentary sources to support a humanistic interpretation of the union of church and state at the Rio Grande in the colonial period. For their helpful assistance in setting priorities for research in Washington, D.C., I am indebted to Dr. George S. Ulibarri of the National Archives; Mrs. Georgette Magassy Dorn of the Library of Congress; and Fr. Antonine S. Tibesar, O.F.M., director, and Fr. José Luis Soto, O.F.M., former librarian, of the Academy of American Franciscan History.

Indispensable to writing a historical account of the Rio Grande outpost of empire were the 1772 inventories of San Juan Bautista and San Bernardo, copies of which Fr. Benedict Leutenegger, O.F.M., of Mission San José y San Miguel de Aguayo in San Antonio, Texas, made available from the microfilm collections in the 0ld Spanish Missions Historical Research Library. To compare the contents of documents and to facilitate the process of deciphering of tentimes illegible paleography, I obtained copies of the 1772 inventories in the Archivo Franciscano of the Biblioteca Nacional in Mexico City. For securing these essential sources, I gratefully acknowledge the important contributions of my former research associate, Mrs. Gloria V. Cadena, of San Antonio, Texas, and Señor David Castañeda of the National Library in Mexiço City. I also acknowledge the assistance of Norma Eulalia Contreras and María Dora Guerra, UTSA graduate students in Borderlands history, who drafted either Spanish typescripts or raw-English translations of the 1772 inventories. Ultimately, my major responsibility became translating, editing and typing the final version of the inventories for publication. As might be expected, a few words defied translation; hence, I left them as they appeared in the document in the hope that future scholars might untangle the knot.

In a very special way I wish to acknowledge the patience and encouragement of my wife, Maria, who during the extended duration of the project maintained a philosophical disposition for what seemed an endless task. To our friend and gifted artist, José Cisneros of El Paso, Texas, I express sincere gratitude for the illustration he designed for the cover, all made possible through the benevolence of the Bexar County Historical Commission and its chairman, Maj. Gen. William A. Harris, U.S.A. (ret.). Another loyal friend, Dr. Barnabas Diekemper, O.F.M., director of the Catholic Archives at San Antonio, frequently offered sound counsel and cheerful humor. Dr. E. Victor Niemeyer, Branch Public Affairs Officer of the International Communication Agency at the American Consulate General in Monterrey, Nuevo León, Mexico, friend and colleague, furnished copies of rare books, not readily available at local outlets, which placed the 1772 inventories in historical perspective. Likewise, Dr. Paul V. Murray of Mexico City contributed a copy of the invaluable Gura del Archivo Franciscano. Dr. J. Manuel Espinosa of the Department of State in Washington, D.C., offered moral support and constructive criticism, as did Dr. Thomas N. Campbell of The University of Texas at Austin. 


\section{INTRODUCTION}

The Franciscan missions of the Rio Grande emerged in the twilight years of the 17 th century as a result of resourceful expansion by frontiersmen of the church and state into the northeastern arc of the Borderlands of New Spain. In the 18th century, the subsequent growth and development of the missions coincided with the political aims of the state to control the middle Rio Grande as a vital corridor connecting Coahuila and Texas to the interior of the viceroyalty.

In the vanguard of Spanish colonial expansion in North America, Franciscan missionaries of the Apostolic College of Santa Cruz de Queretaro established a chain of religious centers from the semi-arid region of the Rio Grande to the humid timberland of east Texas. As initial steps in the long road to Texas, the friars of Querétaro founded three Rio Grande missions, clustered around an adjacent presidio, which became models of spiritual and temporal progress.

The chronological sequence of the mission foundations began on June 24, 1699, with San Juan Bautista on the banks of the Rio Sabinas. Within six months, the Franciscans transferred operations northward to the Rio Grande, near convenient low-water crossings, and reestablished San Juan Bautista on January 1, 1700. Three months later, in the immediate vicinity, the friars reinforced their apostolic work with a second mission, San Francisco Solano.

Situated on the fringe of the Borderlands without adequate military protection, the Queretaran missions in the early years sustained frequent attacks by native marauders. However, encouraged by assurances from the viceregal government that a permanent garrison would be assigned to the area, the Franciscans in 1702 founded a third mission, San Bernardo. A year later, the military established Presidio San Juan Buatista del Rio Grande del Norte at the hub of the missionary activity. Symbolizing constructive aspects of the union of church and state on the frontier, the presence of soldier-artisans enabled the friars to receive material assistance in their preliminary building program.

During the missions' formative years, the Franciscans developed strong temporal foundations that complemented the socio-religious instruction of the native converts. In 1718, responding to the state's priority to support colonial expansion in Texas, the Franciscans suppressed Mission San Francisco Solano and transferred its records, portable equipment and exemplary converts to the banks of the San Antonio River to create the genesis of a modern urban metropolis. Throughout the succeeding decades of the 18th century, the Queretaran friars at the Rio Grande, with determined renewal in the wake of occasional setbacks, consolidated the spiritual and temporal gains of San Juan Bautista and San Bernardo. Together with the presidio, the progress of the two missions contributed to the relative security of the riverside settlements.

Following the inauguration of the Bourbon reforms in Spanish America that resulted in political and military readjustments in the northern Borderlands, in 1772 the friars of Santa Cruz de Querétaro voluntarily relinquished their administration of the Rio Grande missions to the Franciscans of the ecclesiastical Province of Jalisco (Guadalajara). As prescribed by viceregal guidelines, the formal transfer required the compilation of a comprehensive inventory of the mission properties. Accordingly, the commandant of Presidio San Juan Bautista, representing the state, performed the meticulous task of compiling the inventories, beginning with Mission San Juan Bautista in November 1772 and continuing with San Bernardo in December. 


\section{INVENTORY OF \\ MISSION SAN JUAN BAUTISTA OF THE RIO GRANDE DEL NORTE}

Captain Don Vicente Rodríguez, 1 Commander of Presidio San Juan Bautista del Rio Grande:

At the request of the Reverend Apostolic Fathers of the College of Santa Cruz de Querétaro ${ }^{2}$ to Our Most Excellent Lord Viceroy of these Kingdoms petitioning the transfer of the two Missions of San Bernardo and San Juan Bautista to the Reverend Fathers of The Seraphic Observance of the Province of Jalisco of Guadalajara, ${ }^{3}$ I, upon receipt of his recent letter of July 8 of this year [1772], issued authorization for such transfer and inventory of the spiritual and temporal assets, including a Census of the Indian people in residence at each mission. In the event I am unable to perform this [legal] action, which at present is morally impossible, I have delegated the responsibility to Lieutenant Don Josef Castilla y Terán, in whom I have the utmost confidence, to proceed [to the Rio Grande] in company with the Reverend Fathers of Guadalajara, Fray Josef Ponce, Fray Luis de Lizarrana, and other Religlous concerned with the transfer. I have directed them not to waste time in conducting such transfer and inventory, signed by the Religious, leaving at each Mission a certified copy of the transferred property, with a Census of the Indians of both sexes who currently reside in them, assuring that it will be executed with the best harmony, serenity, and tranquility, thus carrying out in this manner the orders in my possession from His Excellency, informing me through reports of the diligences you require in order that I may forward them to $H$ is Lordship as I perceive [the duty]. I anticipate the zeal and conduct with which you will discharge your obligation in this assignment with the exactitude that our Lord has endowed to you.

$$
\begin{aligned}
& \text { Monclova, November 22, } 1772 \\
& \text { Jacobo de Ugarte y Loyola } \\
& \text { [Governor of Coahuila] }
\end{aligned}
$$

At Mission San Juan Bautista [within the jurisdiction] of the Presidio Rio Grande del Norte, on November 27, 1772, I, Don Vicente Rodriguez, provisional captain and chief magistrate of this royal presidio, and Don Josef Castilla y Terán of [Presidio] Santiago de la Monclova, arbiters appointed by Colonel Don Jacobo de Ugarte $y$ Loyola, Governor and Commandant General of the Provinces of San Francisco de Coahuila, Nueva Estremadura, and its presidios, conversions, and frontiers, by the grace of His Majesty whom God keep in good health, as directed by the previous order of November 22 , in response to an [earlier] order dated July 20 of this year from His Most Excellent Lord and Viceroy, Fray Don Antonio Maria de Bucareli y Ursua, 5 Governor and Captain General of New Spain, to achieve the goals they describe; in strict compliance with these directives we proceeded to this [Mission] accompanied by the Reverend Father Commissary, Fray Luis de Lizarrana, and other misstonaries of the Seraphic Observance, along with the presence 
of the Reverend Father Diego Ximenez, president of these [Rio Grande] missions of the Apostolic College of Propaganda Fide [of Querétaro]. I personally informed them of the superior order and commission that mandated our assignment, to which the above-mentioned Reverend Fathers Commissary and President, finding themselves in receipt of the same orders from their Prelates, the Very Reverend Father Provincial of the Province of Jalisco and the Very Reverend Father Guardian of the College of Santa Cruz de Querétaro, for the transfer of these two Missions, currently under the administration of the latter, to the former which is prepared to receive them with all formalities and circumstances required. Accordingly, in compliance with the directives, the Reverend Father President, Fray Diego Ximénez, immediately from this day forward has proceeded with [the inventory] and transfer of Mission San Juan Bautista to the Reverend Father Commissary, Fray Luis de Lizarrana, in the following manner:

\section{CHURCH}

The church is 34 varas 6 long and $7-1 / 2$ wide, with corresponding height. It has a Presbytery 7 and transept; and an elevated garret with four stone arches of the same height as the nave of the church. There are four windows, one on each wall, in the uppermost recess, and two damaged windows in the lower section. The building is roofed with cypress beams, and the floor is of the same lumber, under which are 106 common graves extending approximately to the main entrance.

\section{Ma in Altar}

The main altar, comprising the entire wall, is oil painted and resplendent with the following [religious] images: In the uppermost section is an oval frame of two varas in height, with the image of Our Lady of Light, with its gilded frame and carved pediment. There are two gilded frames of one vara in size, studded with gleaming mirrors, embedded in the wall. There is a carved statue of John the Baptist, Titular Saint [of the mission], of two varas in height, completely ornamented. There is another carved statue of the Immaculate Conception of $3 / 4$ vara in height, attired with an imperial crown on its head and a half-moon at its feet, all of silver with other ornaments of pearls and trinkets. Changes in garments will be discussed in the section relating to the items in the Sacristy. A canopy of purple satin covers the throne of the Immaculate Conception and of the titular saint, and on each side are six tapestries of blue and red satin. On the Gospel side ${ }^{8}$ there is a carved statue of our holy father, St. Francis, of more than a vara in height, decorated in oil colors and mounted on its painted mantelpiece. On the Epistle side, ${ }^{9}$ of the same construction and decoration, is a statue of St. Anthony of Padua. There is a gilded tabernacle, with carved columns, cornices, and spires, for the repose of the Holy Sacrament, with its door, lock, and key, and in the interior are an altar stone and a curtain of 
Toledo satin. Above the tabernacle is a silver cross at the crest and on the door is an image of Our Lady of Bethlehem with its crystal. On both sides of the tabernacle are two tiers covered with Indianilla 10 which serve to display the candles on solemn days [of religious obligation]. Above this pediment, on the Gospel side, is a statue of the Child Jesus of $1 / 2$ vara in height, on a gilded pedestal with a silver laurel wreath and sendal of sheer fabric. On the Epistle side is a statue of our holy father, St. Francis, of the same construction on a gilded pedestal. The altar table is made of cypress lumber, with its altar stone and altar linen of Indianilla and dust cover of the same fabric. Upon it are cross candlesticks and altar cards on the Epistle side. Its crenchall has a small frontal of plush silk and two pedestals of gilded sculpture for the processional candlesticks. On the Gospel side upon the wall is a niche, with its door, lock and key. Inside is a curtain of Toledo satin and a base upholstered of the same fabric for the box in which are deposited the holy oils. The box, lined in green velvet, has four containers, lock and key, and silver corner bands. In the same depository is another small brass box with its small scales and three silver containers for oil and chrism ${ }^{12}$ (which at present is not used). A carved railing of walnut lumber supported with lateral buttresses, with a cypress base, that divides the Presbytery serves as a Communion rail with Rouen cotton tapestries.

\section{Altar of the Holy Crucifix}

This altar, on the Gospel side [of the main altar], is oil painted, its wall resplendent with the following images: In the uppermost section is a picture of our holy father, St. Francis, of two varas in height, in a painted frame. In the center is a Holy Crucifix, two varas high, upon an oak cross, with a dossal, canopy, and curtains of Toledo satin. To the right, upon a painted mantelpiece, is a statue of Our Lady of Sorrows, $1-1 / 3$ varas high, dressed in a tunic of black taffeta, a sash of sheer cloth, a veil of melendra, pectoral cross of Brittany cloth, heart, dagger, and silver laurel crown. Other garments of this statue are listed below. To the left, also upon a painted mantelpiece, is a statue of St. John the Evangelist, of the same height, with its tunic of Toledo satin and cloak of coarse woolen cloth trimmed with ribbon. In a glass case upon the altar, below the Holy Crucifix is a statue, $1 / 4$ vara high, of Jesus the Nazarene. The altar has its stone, linens, candlesticks, dust cover, altar cards, and an old frontal of red satin. On the Epistle side of this altar, suspended upon the wall is a gilded oval frame, $1-1 / 2$ varas high, with gilded carved pediment, within which is a canvas painting of St. Catherine, Virg in and Martyr.

\section{Altar of Jesus the Nazarene}

This altar is on the Epistle side of the amin [altar], oil painted with resplendent images of the following. In the center, upon a 
painted stone pedestal in a niche, is a full-length carved statue of Jesus of Nazareth, two varas high, with a cross on its shoulders, attired in a sheer purple tunic, decorated with silver flowers and trimmed with silver ribbon, with cuffs of Brittany cloth and the opening lined with fine lace. On the right side is a carved statue [of Jesus Christ], 1/2 vara high, with a crown of thorns, attired in a cloak of purple damask. On the Epistle side is another statue of the same height depicting Christ's first fall [the scourging on the road to Calvary], dressed in a white Brittany tunic with narrow lace edging. Below the center pedestal, above the altar, is a Crucifix, 1/2 vara high, of orangewood, with a baldachin of red chalona decorated with a blue stripe on the edge. The altar table is of stone upon which are an altar stone ${ }^{13}$ and linens; the red frontal is old and of ordinary satin. It has a crucifix, brass candlesticks and decorated altar cards.

\section{Main Body of the Church}

Two box-type confessionals constructed of [quality] molding, with half-doors of the same material, all painted.

A pulpit and sounding board of the same material, painted.

Twelve cypress pews, 11 with backrests in the nave of the church, and the other, with carved backrest and bottom flap, in the chapel of the Holy Crucifix.

A font for holy water of fine hewn stone with its matching base; and decorations on the surface.

A music stand, painted.

A choir loft of 4-1/2 varas in depth and $7-1 / 2$ varas in width, with its walnut railing of well-rounded grills, oil painted to produce the effect of tortoise shell-1ike wood; four pews with decoratively carved backrests and armrests. Its entrance [is secured] with door, lock and key, and on the opposite side is another entrance leading to the Tower, with a large casement window in the center and halfdoors.

\section{Tower}

A small tower of $1-1 / 2$ stories in height, approximately $3-1 / 2$ square varas, with four openings in the belfry from which are suspended five bells of the following weights:

First, 10 arrobas 14 and 23 pounds. Second, 9 arrobas and 3 pounds. Third, 8 arrobas and 14 pounds. Fourth, 7 arrobas and 22 pounds. Fifth, 4 arrobas and 11 pounds. 
Outside of the tower, above the flat roof, is another bell, weighing three arrobas and 24 pounds, which serves to call [the faithful] to prayer. At the porter's office is another bell, weighing nine pounds, to announce [the arrival of visitors]. Added [to the inventory] are eight hand-operated bells for the altars, some weighing one pound and others one-half pound, of which only three are actually used; the rest are stored in the Sacristy.

\section{Baptistry}

Inside the main door of the church to the left is the entrance to the Baptistry, with a door, lock and key. In the hollow of the bell tower, outside the main body of the church, the baptistry is roofed and the ceiling is painted, including the crossbeams. On the opposite wall to the entrance is a canvas painting, one vara high, depicting the baptism of Jesus Christ.

A cypress table, two varas long and one vara wide, upon which is a carved ornamented statue of St. Roch with a gold cape.

A copper baptismal font, with copper cover above which is a bronze crucifix about one hand-span long, all of which rest upon a straw mat and a well-cut cypress base. On the wall to the right is a niche with door, lock and key; inside is a box, oil painted, also with lock and key, with two silver containers for the holy oils and chrism. The interior is lined with a curtain of Toledo satin trimmed with ribbon.

A silver shell for the baptismal water.

\section{Cemetery}

Outside the main entrance of the church, in front of the door, is the cemetery extending 29 varas square, enclosed by a stone wall $2-1 / 2$ varas high. There are gates with elevated arches on three sides, and Havana-style pyramids at each corner.

\section{Sacristy $^{15}$}

This room is next to the Presbytery outside the body of the church, with a doorway to the main altar, with lock and key, and an Indianilla curtain, and another doorway to the living quarters, also with lock and key. A large window is on the west side, with its half-shutters [on the outside] and a corresponding full-length grill of well-rounded dowels on the inside. This room is eight varas long and five varas wide; its roof is constructed of cypress planks; its doors and crossbeams are painted. Opposite the wall facing the Presbytery is a chest of drawers, 4-1/2 varas $10 n g$ and one vara wide, the surface of which is covered with leather fastened down with bronze tacks. The chest has four large drawers and six small ones, all tightly secured with their locks and keys. The large drawers are painted. On each side of the same wall are 
two niches, with painted doors and bolts, within which are four shelves to store different alhajas.16 On the same wall and all around the Sacristy are the following statues and canvas paintings: In the uppermost section of the wall is a canvas painting of St. Michael the Prince, five hand-spans high, in a gilded frame. Below [it], on the right side, is another canvas without a frame, three hand-spans high, of the Virgin of Sorrows. Correspondingly, on the left side is another canvas of the Glorious Patriarch, St. Joseph. In between these two are a Holy Crucifix in rellef, three hand-spans high including the cross, and a baldachin of red satin. At the base of the crucifix is a mirror of $1 / 2$ vara in a carved gilded frame from which is suspended a reliquary 17 of skillful craftsmanship, decorated with crystal beads of various colors, with a painting on the inside of St. Rafael the Archangel and a few religious [designs] on the periphery. On the right side of the wall is a gilded and painted frame with a canvas painting of our Lady of Refuge in a short cape, with clamp for handling, with its shade of thin gauze, curtains of blue and red ribbed silk, trimmed with a ribbon. The entire canvas painting measures $1-1 / 2$ varas high. On the same side above the door is a Holy Crucifix in relief, one vara high including its cross of tamarind wood, with baldachin of striped melendra. On the opposite side is a painting depicting a condemned soul, in a frame of cavetto molding with a painted clamp.

Next to the chest of drawers are six writing cabinets arranged in sets of three in ascending order from the largest to the smallest. The three cabinets on the left are lacquered and the other three on the right are oil painted, with different interior drawers, and each with a lock plate and key. The sets of writing cabinets rest upon two tables with well-rounded legs.

An ordinary box, five hand-spans long and three wide, with inlays of different kinds of wood, lock plate and key, for storing white clothing.

Another regular box of cypress wood, larger than five hand-spans long and three wide, with its lock plate and key, for the same purpose. On top of this box is a smaller one, painted, with its lock and key, for storing cylindrical coverings for the crucifixes and processional candlesticks.

Three prester chairs and altar pews of walnut lumber, with wellrounded legs and chiseled artwork; the seat and backrest upholstered in striped plush, studded with gilded bronze tacks, the dustcover of terlinga.

Another [prester] chair, more ordinary, of cypress wood, with well-carved backrest, armrests, and bottom flap.

An octagonal-shaped lead washstand, cast and painted with different designs on each surface, with drain pipe and faucet. On the top 
surface is a lead figurine depicting the Guardian Angel, about 1/2 hand-span high. Underneath in a cypress box is a copper washtub with a well-rounded bottom. Immediately upon the wall is a painted wooden box with a clamp for the hand towel. Above the washbasin is a sign identifying its use.

On the opposite side is a balustrade attached to the wall, with dowel hooks for hanging the vestments of the acolytes. 18

A small box, undecorated, for storing flowers and other triflings.

An open box for storing candlesticks.

in Crates and Boxes in Addition to Those in the Sacristy

Four chalices 19 of regular size and workmanship, three with the interior of the cup gold-plated, as are the patens. ${ }^{20}$ The other one, somewhat larger, is completely gold-plated, inside and outside, and is at the base of the Tabernacle of the Holy Eucharist.

The Tabernacle is square, gold-plated, with four fine crystal ornaments; two ciboriums, 21 one large and one small, gold plated on the inside; ten small silver spoons for the chalices.

A silver processional crucifix, with its silver helve of three varas in length.

Two silver processional candlesticks, slightly shorter.

A silver censer ${ }^{22}$ with $i$ ts matching boat. ${ }^{23}$

A set of silver cruets $^{24}$ and hand bell.

A pair of silver cruets.

An oval-shaped silver pyx ${ }^{25}$ with a silk cord, and a gilded interior arrangement for carrying the Viaticum.

In the cell occupied by the Fathers is a cedar chest with silk cords in which are a silver container with oil for extreme unction and next to it a section lined with blue shag with silk cords containing a manual, crucifix, wax, surplice, and stole.

In one of the [desk] drawers in the Sacristy are 13 silver coins and two bronze rings used as arras [in the marriage rite]. ${ }^{26}$

Two square silver keys, one of which actually is used to open the silver metal rim of a crystal container for offerings; the other key is for a container which is broken.

A silver-plated laurel crown for the Christ Jesus which is on the main 
altar, besides the one already on the statue.

Added to the inventory of silver items already listed under the headings of Presbytery and Baptistry are another container of holy oils not used at present, and three pouches of different silver- and goldthreaded cloth for the ciboriums.

\section{White Vestments}

Twenty-four amices, 2711 of Brittany with lace in good condition, seven in average condition, and the remainder in poor condition.

Twenty-five albs, ${ }^{28} 15$ of Brittany cloth with lace of different widths; some are new and the remainder in average condition.

Thirty-four cinctures of different linings, plain or double, all serviceable.

Seven surplices ${ }^{29}$ of wide Brittany, three new ones with lace from Lorraine, one of Rouen linen, and the remainder of Brittany cloth, mended.

Fourteen altar cloths, including the ones presently used, of wide Brittany with narrow lace trimming, six of which are new, four average, and the remainder worn out.

Sixty-five small altar cloths, all of Brittany linen, in good condition, most with narrow lace edging.

Two-hundred and three purificators ${ }^{30}$ of fine linen cambric, 100 of which are in good condition, and the remaining 103 ranging from average to poor.

Twenty-five corporals, ${ }^{31}$ some of fine linen cambric with fine lace trim and the remainder of Brittany linen, all in good condition.

\section{White and Colored Chasubles ${ }^{32}$}

First, one of gold lame decorated with imitation galloon with matching chalice veils and burses for the corporals, in new condition as all the rest.

Another of medium weight cloth fabric decorated with Mexican galloon, new and useful.

Another of turquoise Persian flowered silk decorated with Mexican gold galloon, new.

Eight ordinary [chasubles] of damask, wool, ribbed silk fabric, and double taffeta, with plain galloon, most of them in good condition 
and the rest average, totalling 11 white vestments.

One of silver cloth fabric with a red background decorated with silver Mexican galloon, new.

Two of medium weight cloth fabric decorated with gold and silver Mexican galloon, new.

Five of Persian silk, Glodetú, damask, satin, and double taffeta decorated with varied plain galloon, all serviceable.

Two green chasubles of Persian flowered silk decorated with blue ribbon and silver galloon, new.

Two purple chasubles, one of Persian silk decorated with Mexican galloon and the other with pink galloon.

A black chasuble of melendra with silver flowers decorated with silver Mexican galloon, new.

Two chasubles, one of damask and the other of ribbed silk, in average condition.

One chasuble of double taffeta, new, in preliminary stages of sewing.

Total Chasubles: 27

\section{Capes $^{33}$}

Two reversible capes of black and white damask, one adorned with decorative braid and double silver fringe, new; the other adorned with imitation tresillo, in average condition.

One of red satin with silver flowers decorated with needlepoint lace, in average condition.

One of purple Persian silk decorated with silver Mexican galloon, new.

Two black capes, one of melendra with silver flowers decorated with silver Mexican galloon, in good condition; the other of damask in average condition.

Total Capes: 6

\section{Antependiums ${ }^{34}$}

First, an antependium of white gold lamé decorated with gold Milanese galloon with matching fringe, new.

One white of Persian flowered silk with silver fringe [decorated with] 
gold needlepoint, new.

Seven of Persian silk, wool, and smooth satin decorated with different plain galloon, in average condition.

One of red damask with gold flowers decorated with matching galloon, in good condition.

Four of Persian silk, Chinese silk, damask, and smooth satin decorated with plain and silver galloon, in average condition.

Two of purple Persian silk, one new and the other in average condition.

Two green antependiums, one of Persian silk with silver galloon, new; the other of flowered satin decorated with trencillo, average.

Two black antependiums of melendra decorated with silver Mexican galloon and fringe; the other of Inue, in average condition.

Tabernacle Veils

Nineteen of uniform size in the colors of the antependiums and vestments described above, all serviceable.

\section{Coverings for Processional Crucifixes and Candlesticks}

Twelve of the colors matching the [above-listed chasubles] of which two sets of black and white are new; the remainder are in average condition.

Six surplices of terlinga, three [Franciscan] habits of blue fabric from Querétaro.

A wardrobe for the acolytes.

Four sashes of Persian silk and satin of different colors.

A square cover of Indianilla fabric with its skirt decorated with elegant ribbon for the processional ceremonies of Our Lady, composed of a cypress table with four legs and arm supports and four lanterns at each corner.

Another ordinary processional table of cypress for St. John the Evangelist for the ceremonies of Holy Week.

Another ceremonial table of the Holy Sepulchre used on Good Friday, oil painted, with its quilt, coverlet, and pillowcases.

Two and one-half varas of melendra and three varas of taffeta 
to make garments for the Virgin Mary.

Another 2-1/2 varas of fabric to transport the deceased to the church.

A carved side altar, painted, with four columns and matching cupola and ladder.

A table, 2-1/2 varas long and five hand-spans wide, for the ceremonies of the church.

A very faded red damask tabernacle cover, square, of regular size.

Six carpets, three of colorful craftsmanship, and the other three of plain striped wool, plus two other black carpets, very old.

For distributing the Sacred Viaticum there is a small cape of lightweight fabric, a gold strip border, and a flowered frontal matching the above-mentioned cape.

Six small branches of flowers in gilded pots studded with pieces of mirror, plus different jars, flower pots, and colored clay pottery for the same purpose.

Six lanterns, two of tin and the other four of wood and paper.

Four missals, three in average condition and the other worn out.

Four manuals, two [published in] Rome and the other two in Mexico.

Two other doctrinal manuals in the dialect of the tribes of this region.

Six altar stones of different petrous materials; the three which are presently used are large and the others are standard size.

Twenty-five metal candlesticks, of which six are new and the others in average condition.

Three basins for holy water.

Two iron molds for making hosts and two boxes.

A violin and a guitar for the liturgical music of the church.

A clapper used for Holy Week.

A wrought iron base, painted, for the Paschal Candle.

\section{Vestments for the Statues}

Twelve cloaks of all colors for the Immaculate Conception, five of 
which are embroidered with gold and silver flowers, the rest of Persian velvet.

Four skirts for Our Lady of Sorrows, three of black satin and ribbed silk, and the other straw-colored.

A blue cloak with silver galloon, used.

A tunic for Jesus the Nazarene, lined in piquén, used.

Another tunic of red lustrine with a narrow silver trim.

Different remnants, discarded and trifling, are in a box of spare garments labeled for mending clothes.

Added to the inventory is a cypress platform at the base of the chest of drawers in the Sacristy, covered with a woolen carpet of black and yellow stripes, measuring four varas long and three wide.

\section{LIVING QUARTERS IN THE CONVENT}

This complex is made up of an interior patio of 38 square varas surrounded by 12 rooms or cells, including the kitchen, at ground level. All rooms have doors, lock plates and keys, and windows and window guards, some with two windows, stone walls, and plank ceilings with double terraced roof. Next to the porter's office is the main gate of three arches, with an inner gate and a larger gate with its postern, large knocker, lock plates and keys.

In the center of the complex is the granary with grain bins measuring 29 varas long and eight wide, with corresponding height, stone wall with a flat roof of planks and mortar, interior dividers, stone floor, and grain measures of $1 / 2$ fanega ${ }^{35}$ and an almud. ${ }^{36}$

In the same vicinity outside the living quarters is the weaving shop for the Indians' clothing, which is a building 28 varas long and seven wide, with three pillars in the center, ten large windows in a wall of stone and mortar, door, lock plate and key. For the work there are the following items:

Three looms, all assembled and equipped.

A warper with 12 yarn guides.

Two bobbins.

A winding frame with foot pedals.

Fifteen spools of ordinary thread.

Two redinas.

Seven pairs of combing cards.

Eleven pairs of cards for second combing.

Three smooth wool weavers with combs.

Eleven pairs of combing cards of all types, used.

Three dozen spindles, used.

Five crates of spare parts. 
Adjacent to the weaving shop is the blacksmith's forge, with its separate walls of stone, a grill window, and door. It is equipped with the following tools:

A bellows stand with its iron tubes and copper funnel.

A medium-sized anvil.

Three cold chisels.

A sledge hammer.

A nail head mold.

Two hammer heads.

A hammer.

Three hammers with cutting edge.

Two straight pliers.

Two vises.

Two drills with drill bits.

Twelve files of all types.

A diestock with seven molds.

A drawplate and two drills.

An escreadr and one perforator.

Seven awls for hot-tempered metal.

Three awls for cold-tempered metal.

A file cutter.

A bench with a two-beaked anvil.

Four anvil drills.

A crowbar.

Two pairs of pincers.

A burnishing wheel of three ridges.

Three burins.

A scraper with a drill.

A grappling iron and one crucible.

A soldering iron.

A table, box and key.

A box for tools.

A leather chest protector.

A hoof parer and one hammer.

INDIAN PUEBLO

From the front of the Convent, the Indian quarters extend westward for 71 varas; they include 31 dwellings with walls of stone and mortar, some with doors, lock plates and keys. The tribal families who reside in them enjoy the benefit of the following:

A shed in the middle of the compound, very spacious, to protect the carts, animals, and a few planks of lumber. On the north end of the Indian quarters is a rock kiln for burning lime.

Outside the building area is a corral with a palisade fence, 42 varas square, for the livestock, with a gate of upright stakes and trams.

In back of the mission is a garden enclosed by a fence of timber posts 
for vegetables and fruits, about half a fanega ${ }^{37}$ under cultivation and irrigation, including rows of beans and cotton, and orchards. It has an irrigation ditch to convey water here from its headspring 12 to 14 leagues 38 away. There is a gate of upright stakes and crossbars, spacious enough for a cart; in the storage shed in the center are 14 plows. In the mission's workshop are the following tools for cultivation:

\section{Farm Equipment}

One hundred and four plows.

Twenty-four hoes.

Twenty yokes.

Eighteen pairs of straps for yoking oxen.

A new cart.

Three iron shovels.

Thirty-nine axes.

Seventeen iron bars.

Fifteen yoke rings.

Five carts in average condition.

\section{MISSION RANCH}

Approximately six to seven leagues to the southeast is the Mission's ranch. There is a flat-roofed house with stone walls; it has a patio, parlor, a kitchen, and two other rooms, and doors with lock plates and keys. On one side of the house is a corral of timber posts, 25 varas wide and 36 long, with bullpen and pigsty. Living on the ranch at present are 16 persons who assist in the work of looking after the major livestock and horses. In turn, each worker receives room and board. The ranch equipment is as follows:

A new cart.

Three yokes.

An iron bar.

A short spear.

A hoe.

An ax.

Three pairs of straps for yoking oxen.

Two riatas.

A large pot.

A rifle.

Two blunderbusses.

Gunpowder and ammunition.

ALHAJAS, TOOLS, PROVISIONS AND EFFECTS WITHIN THE MISSION

First, seven bedsteads, two of which are for the missionaries, and the rest are in the different rooms.

A protective net of coarse cotton fabric and one shaving towel. 
Two colored bedspreads for guests and three white ones.

Four mattresses of terlinga.

One mattress of finer quality for the Holy Sepulchre on Good Friday.

Twelve pillows and four pillowcases of Rouen linen.

Six bedsheets of the same material.

Four copper drinking tumblers, serviceable.

Four tables of different dimensions, besides the ones previously itemized.

Four cypress benches with bottom flaps and backrests.

Fourteen cypress chairs.

Five tablecloths and 12 dinner napkins.

Four cases of shelves of the same material [cypress], the large one with three half-doors, lock plates and keys; the other three, without doors, are used as bookcases, with two breviaries of the holy office.

A small box of stationery, with its separate embroidered compartments, lock and key.

Two inkwells, two sandboxes, and two boxes of sealing wafers with erasers and scissors.

\section{ARCHIVE}

A large writing desk with five boxes or drawers, which currently is used as the Archive. It has a desk lid, lock plate and key, and contains the following papers and books:

\section{First Legajo $^{39}$}

The Mission's document of foundation, various dispatches from the Superior government in behalf of the Indians; certificates attesting to their loyal conduct in [military] campaigns; testimonials presented to the King Our Lord regarding their services; claims, litigations, and judgments concerning their lands, and other papers totalling 25 documents, some of which are more specifically recorded in other parts of the Inventory.

\section{Second Legajo}

This is included in the contents of the first legajo. 


\section{Third Legajo}

These documents pertaining to the Church, compiled with diligent care, are Marriage Records from the year 1716 to 1737, inclusive.

Fourth Legajo

The same Marriage Records continue from the year 1738 to 1750 .

Fifth Legajo

Similarly, the Marriage Records continue from the year 1751 to 1760 .

Sixth Legajo

Idem, from the year 1761 to 1769 .

Seventh Legajo

Idem, from the year 1769 to 1772 .

\section{Eighth Legajo}

This contains different ecclesiastical decisions by the Episcopal Tribunal regarding various dispensations in marriage cases for al1 the years of this administration. All of the actual proceedings, as governed by the Holy Church, involving affairs of the Missions regarding tithing, were in compliance with the decisions on this subject by His Excellency the Viceroy and in accord with the [diplomatic] agreement with the Holy Church. 40

\section{Entry Books}

In the Archive are filed the books of entries regarding baptisms, marriages, and burials, for Spaniards as well as for Indians (although separate), which are the following:

\section{Indians}

There are five books of baptisms, marriages, and burials. The first was begun in the year 1700 with the baptismal entry for Juan Bautista and continues until the year 1718 . It has 46 fojas 41 comprising 434 entries, ending with the entry for Pedro valero.

Actually, in all five books, the entries for Indians are separate from the entries for Spaniards, the totals for whom are as follows:

$\begin{array}{ll}\text { Baptisms of Indians: } & 598 \\ \text { Marriages of same: } & 362 \\ \text { Burials of same: } & 228\end{array}$


Spaniards

There are five other books of entries, apart from those mentioned above for the Indians, and in them are the following entries:

Baptisms: First Book

The first book of baptisms of Spaniards was begun in the year 1703 with the entry for Juan Domingo; it has 33 handwritten fojas with 152 entries of baptisms, the last of which is for Miguel Longoria in the year 1722 in the fifteenth folio. ${ }^{42}$

\section{Burials: First Book}

In this same book, commencing with the fifteenth folio, are 80 entries of burials, beginning with that of Pedro Párvulo, ${ }^{43}$ and ending with Pedro Menchaca, covering the same years.

\section{Marriages: First Book}

In this same book are 43 entries of marriages of Spaniards, extending from the twenty-fourth folio to the thirty-third, beginning with the entry for Nicolás Maldonado and ending with that for Buenaventura Menchaca in the referred years.

Baptisms: Second Book

The second book of baptisms of Spaniards was begun in the year 1732 [sic], commencing with the entry for Juan Antonio; it has 145 handwritten fojas with 876 entries, the last of which is for Blas Maria [in the year] 1771 .

\section{Baptisms: Third Book}

The third book of baptisms of Spaniards was begun in the year 1771 with the entry for Maria Gertrudis, and it continues to the present year of 1772 with 52 entries up to the tenth folio.

\section{Burials: Fourth Book}

The fourth book was begun in the year 1745 with the entry for Antonio Cantun and it continues to the present year of 1772, up to the thirty-ninth folio, and contains 334 entries.

\section{Marriages: Fifth Book}

The fifth book of marriages of Spaniards was begun in the year 1734 with the entry for Marcos Joseph Hernández; it contains 168 entries up to the thirty-sixth folio and continues to the present year, adding these entries of Spaniards to the preceding documentation found in the Books of Indians, totalling the following: 
Baptisms of Spaniards: $\quad 1,080$

Burials of Spaniards: $\quad 414$

Marriages of Spaniards: 211

Boxes

A book in its slipcase of the accounts of this Mission.

Eight boxes, large and medium, with lock plates and keys, one painted, another leather-covered and old.

\section{Gun Rack}

A cypress gun rack for rifles and escopetas. 44

Weapons

Two inexpensive rifles; another without a trigger.

Three escopetas in need of repair.

Three blunderbusses, two powder flasks, two pairs of ammunition pouches and a bullet mold.

A quiver of ordinary arrows.

A small French rifle.

A leather pouch with 18 charges [for bullets].

Two [pouches] of gunpowder, six pounds of one-ounce bullets and four pounds of half-ounce bullets.

Two hacking knives and different gun barrels, loose.

\section{Glassware}

Two bottle cases, one with 15 bottles and the other with 12, with lock and key. Idem, eight bottles larger than three azumbres 45 and five bottles of $1-1 / 2$ azumbres.

Two crystal glasses and a tin funnel.

Two decanters.

Two vials for oil and six ventosas. 46 


\section{[Storage Closet]}

Thirty-one copper cups, 34 minus 14 deep serving bowls.

Twelve tin pots from Guadalajara.

Eight milk pitchers

Three fine plates.

Ten plain small cups, one fine large earthen jar, and one large narrow-mouth pitcher.

Sixteen dozen small brushes.

Thirty-two sacks, of which 24 are of burlap and four of leather.

Nine large burlap sacks.

Four taper candles and $1 / 2$ dozen candle snuffers.

A shaving pouch with eight razor blades, a mirror, six dozen and five pairs of shearing scissors [for wool].

Two pairs of tailor's scissors.

Three Roman balances, two of which are hundredweight capacity and the other of two hundredweight capacity.

Seven branding irons, three distinct branding marks, one leather strap, one fire poker, and three small branding irons.

Two sieve-hole punchers.

Twenty-four large willow baskets and one small one.

Seven gourd cups and two wooden tubs.

A copper tub and one large bas in of metal from China.

Two scales, one small and the other large, in addition to the one listed under the heading of workshop.

\section{Carpentry Shop}

First, eight chisels and 16 small chisels.

Three clinchetes.

Two box saws.

Two drag saws.

A large hand saw and a smaller one. 
Eleven saw blades, loose.

Two pruning hooks.

Four large augers.

Twenty-four small augers.

Four gouges and three small nails.

A chisel for cutting circular objects and three relices.

Four carpenter's planes and two jointing planes.

Four molding planes and one grooving plane.

Three rabbet planes.

Twa filderetes.

Two large smoothing planes and two carpenter's planes.

Six blades, loose, for smoothing planes.

A rabbet plane.

A veneer press.

Ten adzes with short handles.

Three adzes with long handles.

An adze for gouging.

A drawing triangle or set square.

Two carpenter's squares.

A square.

Two metal points.

Nine standard-sized boards and six medium-sized.

An oak workbench.

A container with 18 pounds of nails of all types.

Four additional planks and one board of cypress.

Masonry Shop

First, 14 stonecutter's picks, two cold chisels, and one drill. 
Nine trowels, two plumb bobs, one ramrod, and one mason's level.

A mason's square, two stone chisels, one rule, one batch of lime.

Eighty-seven arrobas of white wool, soiled.

Fourteen arrobas of black wool.

Sixty arrobas and one pound of cotton.

Five arrobas and nine pounds of lead.

Seven arrobas and six pounds of flat metal.

Five arrobas of old copper.

A crate of old pieces of iron and bronze.

Twenty-three pounds of steel.

Two metal pieces of equipment for a saddle.

Four cámaras para hacer salva, and two unserviceable.

Eight shackles and two fetters.

An oak pillory with ten holes.

Ten new saddle trees and four old ones.

Four more saddle trees which are in the field.

Twenty-four hoops for spinning wheels.

Seven hoops with sieves.

Two kneading troughs.

A wooden shovel and two sieves.

Twenty-three candlesticks de la tierra. 47

Forty pesos of tallow candles at the [exchange] rate of 16 to one.

Thirty-one fanegas of salt.

Four fanegas of old beans and 40 strings of chili.

Nineteen dozen [pairs] of leather shoes.

Sixteen dozen smal1 brushes.

Five dozen piloncillo 48 molds. 
Three hundred and eight pesos of piloncillo at the [exchange] rate of 16 to one.

An arroba and a half of indigo.

Nine pounds of copal [resin].

Six pounds of verdigris.

Six pounds of ocher.

Seven pounds of carmine and nine pounds of gold velveteen.

One hundred and three dozen [spools] of smooth ribbon.

A large needle for sewing sacks.

Four hundred stringing ne'edles.

A thousand darning needles.

Three paper tapes of sewing needles.

Two bolts of Holland linen.

A new unopened bolt [of Holland linen].

A canoe suitable for crossing the Rio Grande during the rainy season.

\section{Kitchen}

The following bowls and cooking equipment are currently being used in the kitchen:

First, two copper kettles and a pot.

A copper jug.

Four pots de la tierra and one pitcher.

Two large iron ladles.

Five metal plates from China.

Three bowls and three pots for boiling.

A copper skimmer and a skillet.

A bronze pestle.

A knife, a large pointed knife, and one ax.

Two smail pots and their molinillos. 49

\section{Table Service}

Eight metal plates from China.

Ten metal spoons from China, 29 forks and three knives. 
Five copper pots weighing 67,69 , and 71 pounds.

Another copper pot weighing 73 pounds presently containing 42 pounds of melted tallow; three copper saucepans, and three smaller pots.

Five copper pitchers for water.

Two new copper skillets.

Two new iron spoons and one of wood.

Ten new corn grinding metates and two old ones.

Five pots de la tierra of two-arroba capacity and one of 1/2-arroba capacity.

Half a ream of writing paper.

A pound of incense.

A half-pound of lavender.

A half-pound of marjoram.

Two ounces of saffron.

Four ounces of cinnamon

An ounce of twisted silk of all colors.

An ounce of silk, untied, of all colors.

Eight and one-half varas of silk thread or reata fiber.

Twenty-four and one-half varas of closely-knit blue ribbon.

Five ounces of muñequilla thread.

An ounce of fine thread.

A paper tape with 16 dozen straight pins.

Two and one-half ounces of gold galloon.

Twenty varas of imitation copper galloon.

A vara and a half of white and silver ribbed silk fabric.

Six varas and three hand-spans of red ribbed silk fabric.

An ounce of silver fringe and needlepoint.

Two varas of Milinaque.

Eight varas of fine narrow lace from Lorraine. 
Twenty-eight varas of fine narrow lace [from Lorraine].

Thirteen and one-half varas of lace of a lesser grade.

A box with single beaters and one syringe.

A half pound of sanalotodo 50 ointment.

A pound and a half of vulnerary powders.

A box with four pounds of cañafistula. 51

Two round boxes.

Five arrobas of sugar.

A half-pound of cinnamon.

Three arrobas of rice.

Two and one-half arrobas of quality chocolate.

Two and one-half arrobas of ordinary chocolate.

A short-necked ewer of olive oil.

A barrel of wine.

Seventeen boxes of caramel candy.

Three tercios 52 of flour.

Three tercios of tobacco.

Twenty-four arrobas of soap.

Twelve pounds of alum. ${ }^{53}$

Four pounds of minium. ${ }^{54}$

Four pounds of vermilion. 55

Four pounds of ceruse. 56

Two quarterns of blue cloth and one of negrillo.

Two lengths of thick flannel.

Three lengths of narrow Brittany cloth.

One length of Rouen linen.

Two lengths of Spanish ribbon.

Six lengths of Chinese ribbon. 
A gross of rosaries.

Four bundles of beads.

Six dozen tombac rings.

Six dozen earrings.

Two dozen garment scissors.

A flat iron to press the vestments of the Church.

Twenty-four hoes.

Three dozen small bowls and one dozen gourd cups.

A tercio of corn grinding metates and another tercio of corn grinder pestles for them.

Nine harness bits [for horses].

Three mestizo harness bits.

Twelve new copper kettles, 12 small copper dippers.

Twelve iron shovels, half an arroba of steel.

Four dozen large pointed knives; four pounds of wire.

Eight pounds of blue and white agave thread.

A small trunk of muñequillo thread.

Four dozen woolen stockings.

Four skeins of arria thread; 25 ordinary hats.

Eighteen pairs of leather shoes and 12 pounds of peznegra.

A short-necked ewer of fir tree resin. ${ }^{57}$

Four dozen ordinary glasses.

An arroba of wax processed in the north. 58

A Paschal candle, weighing six pounds.

Twenty-seven candles, four to a pound.

Six pairs of cards for carding wool a second time.

Two hand lanterns. 
Four blank cash books.

ASSETS OF THE FIELD

This Mission has livestock in the following categories:

Cattle

Brood cows

482

Calves, branded

Bulls

38

Tamed oxen

$\overline{672}$

Herds of Mares

There are 16 herds for a total of 526 brood mares:

Brood mares

Stud horses

Colts 104

Yearling mules

Altogether, they total: $\frac{52}{698}$

Integrated with the herds are:

Stud jackasses

Tamed horses

Tamed jennies and jackasses

Jennies [presumably untamed]

[Grand Total: $\quad 1,641]$

Minor Livestock: Wool-Producing Sheep

Out of 5,325 head of livestock, the following categories are formed:

Brood ewes

Rams

4,430

781

Lambs

$\frac{114}{5,325}$

Minor Livestock: Long-Hair Wool-Producing Goats

Female goats for breeding

Male goats

Kid goats 
CENSUS OF CONJUGAL FAMILIES AND TRIBAL GROUPS

WHO ACTLALLY RESIDE IN THIS MISSION

\section{Conjugal Families}

Names

Tribal Group $^{59}$

Migue1

Estefania, his wife

María, their adult daughter

Mescal

Mesca 1

Mescal

Juan Chaguan, Governor 60

Rosa, his wife

Pastacalo

Yugana

Juan Cortinas, Alcalde of the First Ward

Feliciana, his wife

Pacoa

Pastalaca

Bernardo, Alcalde of the Second Ward, Widower

Pampopa

Francisco de Andrea, Fiscal

Mescal

Polonia, his wife

Gertrudis, their young daughter

Maria de los Santos, their other young daughter

Sixama

Sixama

Sixama

Juan Pedro

Luisa, his wife

Mescal

Patacal

Joseph Tres

Mescal

Marcelina, his wife

Pampopa

Rosalia, their young daughter

Pampopa

Luis Punteño

Pitta

Antonia, his wife

Pampopa

Diego Aguillón

Onofra, his wife

Antonio, their young son

Cacsaputas

Mescal

Mescal

Estévan

Juana, his wife

Bernardo, their young son

Patacalo

Pastal[a]ca

Pastal[a]co

Joseph Aguilera, squatter

Juana, his wife

Antonio, their young son

Mestiso 61

Mestisa

Mestiso

Luis Carretero

Mescal

María Guadalupe, his wife

Zifama

Tiburcio

María de Jesús, his wife

Pacsaca

Salvador, their young son

María Regina, their young daughter

Pampopa

Pampopa

Pampopa 
Phel is [Félix]

Marja Antonia, his wife

Maria Josefa, their young daughter

Pacoa

Coyota

Coyota

Manuel de Andrea

Mescal

Marcela, his wife

Pacoa

Francisco, their son

Pacoa

Jacinto, their son

Pacoa

Joseph Antonio Pollo

Maria Ygnacia, his wife

Gertrudis, their daughter

Jacoba, their daughter

Patacalo

Maraquite

[Maraquite]

[Maraquite]

Pedro Saldaña

Paula, his wife

Francisca Andrea, their young daughter

Patalaco

Mestisa

Mestisa

Pedro Celestino

Juana, his wife

Pampopa

Mescala

Joseph Miguel Saldaña

Patalaco

Rosa, his wife

Rosalia, their young daughter

Campacuas

Juana, their young daughter

[Campacuas]

[Campacuas]

Joseph Chamorro

Dominga, his wife

Leandro, their young son

Maria Gertrudis, their young daughter

Pedro Gómera

Mariana, his wife

Marcelino, their young son

Pacoa

Pastalaco

[Pastalaco]

[Pastalaco]

Pampopa

Cachsaputa

[Cachsaputa]

Joseph Antonio Gordo

Maria Dolores, his wife

Bernarda, their adult daughter

Balttasar, their young son

Maria de Jesús, their young daughter

Joseph Gusara

Ysavel, his wife

Fernando, their young son

Antonio, their young son

Pedro Chino

[Rosa,] his wife

Pampopa

Achogtal

[Achogta 1]

[Achogtal]

[Achogtal]

Mescal

Maraquite

[Maraquite]

[Maraquite]

Pacoa

Pacrata

[Francisco] Payaya

[Casimira,] his wife

Santiago, their young son

Caxapa 
Lucio Josefa, his wife Rosa, their young daughter

Blas, their young son

Joseph Antonio Chavira Yñes, his wife

Juna Toro

Francisca, his wife

Mescal

Pastalaco

[Pastalaco]

[Pastalaco]

Pampopa

Pampopa

Pacoa

Pampopa

Joseph Miguel Maior

Matiana, his wife

Achoj

Pampopa

Manuel Cojo

Antonio, his wife

Eusevio, their young son

Juan Manuel, their young son

Patacaco

Maraquite

[Maraquite]

[Maraquite]

Manuel Payoso

María Cándida

Mathias, their adult son

Pampopa

Campacuas

Bartolome, their young son

[Campacuas]

[Campacuas]

Joseph Antonio Delgado

Gertrudis, his wife

Vital, their young son

Pampopa

Coyota

[Coyote]

Pablo

Luisa, his wife

Francisca, their young daughter

Pampopa

Pampopa

[Pampopa]

Christóbal

María Josefa, his wife

Maraquite

Maraquite

Francisco Menor

María de San Juan, his wife

Pampopa

Pampopa

Widowers and Widows With Their Families

\section{Widowers}

Andrés

Pampopa

Thoribio

Palacalo

Andrés, his young son

Jal amo

Tomás

Juana, his adult daughter

Polonia, his young daughter

Antonio Sargento

Cacsopota 1

Gabrie1

Ohayay 
Angél

Daniel, his adult son

Chaparro

Pedro Nolasco

Patacalo

Juan Domingo

Juan Joseph, his widowed son

Patacalo

Thomás Salinas

Pastalaco

Ygnacio Ronderas

Achoj

Juan Pomuceno

Pacoa

Fel is Varaona

Pampopa

Juan de Díos

Pastalaco

Gregorio

Pampopa

Gertrudis, his young daughter

Pampopa

Diego Sánchez

Widows

María Magdalena

Pastalaco

Andrea

Mescal

Juana

Pujan

Anna

Juisonid

San Juana

Pacoa

Candelaria

Pacstacal

Ana María

Cleuterio, her adult son

Borrada Joseph Pedro, her young son Joseph Manuel, her young son

Maria Trinidad, her young daughter

Orphaned Men Without Fathers and Mothers

Pedro Domingo, adult

Maraquite

Benito, adult bachelor

Campacuas

Manuel, adult bachelor

Maraquite

Daniel, adult bachelor

Mescal 
Miguel, adult bachelor

Mescal

Roque, adult bachelor

Mescal

Casimiro, adult bachelor

Maraquite

Simón, adult bachelor

Pampopa

Nicolás, young boy

Pacstacal

Catechumens ${ }^{62}$ and Their Families

Rosa's mother

Rafael, her young son, baptized

Campacuas

The crippled Borrada woman

Santiago, her adult son, baptized

Juan María, her adult son, baptized

Gertrudis, her young daughter, baptized

La Capitana 63

María de la Luz, her daughter, baptized

Campacuas

Cayetano's wife

Campacua

Clara's mother.

Campacua

San Juan's mother

Campacua

Payaya's mother-in-law

Campacua

Bachelors

Pedro Domingo, adult

Maraquite

Juan Joseph Bueno, adult

Yujan

Juan Pachana, adult

Pastacalo

Juachín, adult

Pactacal

Juan Antonio, adult

Pactacal

Juan Peres, adult

Pampopa

Felipe, adult

Pastacalo

Martín, adult

Pactalac

Pedro Relox

$\operatorname{Ac}[h] \circ j$

Diego Coahuila

Pastal 
Fugitives

\begin{tabular}{lc}
$\begin{array}{l}\text { Ramón, adult bachelor } \\
\text { Joseph Antonio Reinosa }\end{array}$ & $\begin{array}{c}\text { Maraquite } \\
\text { [Vital Statistics] }\end{array}$ \\
\multicolumn{2}{c}{ Burrado } \\
Conjugal Families \\
Widowers and Widows \\
Bachelors and Orphans \\
Offspring of Families: \\
Adult and Young \\
Catechumens & 23 \\
Total Population in the Mission & 23 \\
Receiving Communion & 48 \\
Participating in Confession & 169 [sic] \\
Males & 127 \\
Females & 7 \\
\end{tabular}

A1l of the families and others identified in the preceding Census occupy the 30 houses of this Mission. Distributed in the housing units is the domestic equipment given to each family in the form of metates, griddles, pots and pans, and other kitchen accessories.

In the month of October, as in other years, blankets were woven for the young and old for their use as wraps in cold weather. Likewise, all of the Indian people have been clothed in garments made from the cloth produced in the Mission workshop. The work clothes that were made for the men include cotton pullovers and breeches, and, respectively, for the women outer skirts of coarse cotton cloth woven in the same workshop, underwear, petticoats, and blouses. In addition, from the textiles produced in the local workshop breeches have been sewn for all the men, flannel jackets for some men, and skirts for the women, to wear on festive occasions.

For its operation until the next harvest, the Mission at present has 80 banegas of old corn, and approximately 40 fanegas from the recent harvest, six fanegas of old beans and 44 from the new crop.

This year 8-1/2 fanegas of corn were planted, and al though that crop has not been harvested, it has been managed along practical lines in six fanegas [of cultivation].

A Bill of Exchange, dated September 1 of this current year, in the amount of 724 pesos and four reales, signed by Don Miguel Bartolomé Palomo, vecino of the Presidio de Santa Rosa, in favor of this Mission and charged against the account of Don Diego Vallesteros, resident and merchant of Mexico City, was made possible by the provisions of corn and livestock which this Mission supplied to the troops of his command. 
This Mission has asseţs in the amount of 79 pesos and seven reales, administered by the Sindico of the Missions, as a result of the cargo they dispatched for provisions this year of 172.

Likewise, to its credit are 2,790 pesos and five reales, accounts due from various subjects as reflected in the registration and subtraction of accounts made in the presence of the interested parties in the new account book signed in one or several sections.

All accounts due by the Mission, including salaries of the servants of this Mission, up to the first day of December of this year, have been paid.

In the foregoing manner, described in specific detail, the spiritual and temporal assets of this Mission San Juan Bautista, and the Christian Indians, Neophytes, and Catechumens of both sexes and all ages who reside in it, according to these inventories under the care of the Reverend Father Fray Diego Ximénez, President of these Conversions, have been transferred to the Reverend Father Fray Luis de Lizarrana, Commissary of the [Province] of Jalisco. After receiving and accepting each specie in the manner mentioned above, the Mission's assets are now under his care and administration. Regarding the ever-present meticulousness, vigilance, carefulness, and exactitude to which the Reverend Father President and his Missionaries devoted long hours in discharging their responsibility to education and catechism, as evidenced by the testimony of individuals of this Mission concerning their economic development, we declare to the College of Santa Cruz de Querétaro, in the name of His Majesty, whom God keep [in good health], that it is relieved and exonerated of the spiritual and temporal care of this Mission, and we extend proper gratitude to the Reverend Missionary Fathers. In the meantime, an order [arrived] from the Governor of the Province, which he sent on the first day of this month, directing Lieutenant Joseph Castilla y Terán, who assisted in these duties, to proceed immediately in command of the troops of the Presidios of this Province, and those of San Sabá, comprising 110 soldiers, to join the forces of Lieutenant Colonel Don Hugo 0 'Conor in the Sierra de las Ánimas, or Bolsón [de Mapimî], where he will find him on assignment for the royal service. I, the captain, will remain here to continue the Inventory of Mission San Bernardo. We verify the foregoing to the Most Excellent Lord Viceroy of these Kingdoms by signing this document with the Reverend Fathers at this Mission of San Juan Bautista del Rio Grande del Norte.

December 5, 1772

/s/ Fr. Luis de Lizarrana, Commissary

/s/ Vicente Rodriguez

/s/ Fr. Diego Ximénez, President

/s/ Joseph de Castilla y Terán 
TESTIMONY OF THE FORMAL TRANSFER OF

MISSION SAN BERNARDO OF THE RIO GRANDE DEL NORTE

TO THE

REVEREND FATHERS OF THE SACRED PROVINCE OF JALISCO, YEAR OF 1772

I, Don Vicente Rodriguez, provisional captain of this Presidio of San Juan Bautista del Rio Grande del Norte, and commissary in behalf of Our Lord the Governor of this Province [of Coahuila], Don Jacobo de Ugarte $y$ Loyola, for the purpose and transfer of these Missions of San Juan Bautista and San Bernardo, as a result of the superior order of His Excellency the Viceroy of New Spain, which accordingly is referred to at length in this decree that preceded the transfer of Mission San Juan [Bautista], proceeding to this [inventory] of San Bernardo with the Reverend Fathers Commissary and President, commissioned by their respective Prelates for the transfer and acceptance of said Missions and beginning with the Church, [affirm that] the following was found:

\section{CHURCH}

First and foremost, an old Church [measuring] 27 varas long and 4-1/2 varas wide, [constructed] of adobe and stone and mud of recent duration, with its Baptistry and Sacristy, with its good doors, and the entire [structure] plastered. This Church has three altars, a good pulpit made of lumber, two enclosed confessionals and another of only chair, railing, and platform; three benches and four stools. Two steps divide the Presbytery in which is a [carved] grating of the communion rail and two pedestals for the processional candlesticks.

\section{Main Altar}

The main altar consists of three baldachins decorated with beautiful satin with their [background] curtains. Under the principal baldachin, which is in the center, there is a well-carved statue of San Bernardo, $1-1 / 2$ varas in height, with its gilded pedestal. It has green woolen curtains adorned with fine silver needlepoint. The statue rests upon a large mantelpiece of wood, covered in dyed cotense, and three painted octagonal steps. Of the statues under the principal baldachin there is the Child Jesus of Naples, three handspans high, attired in a red damask tunic, Brittany shirt, sandals of ribbed silk, crown of silk flowers; and in one hand a crystal cross and in the other a basket of ribbed, stuff-worked silk, filled with satin fruit; it has a belt of various precious stones. To the right upon a lower step is a carved statue of Our Lady of Sorrows, about three hand-spans high, with its gilded background. It has a crown with rays and silver dagger [piercing the heart]. On the other side there is a gilded carved statue of St. Joseph with the Christ Child, of the same dimension, upon a gilded pedestal. It has a wooden, gilded staff and crown. On the last [octagonal] step over the altar there is a new inlaid, gold-plated tabernacle, with its door and key, [and] pendent of sheer cloth ribbon. The altar is 
[constructed] of boards of lumber and has its platform and table in the center. To one side is a small bell to ring for the Sanctus. 66 In one corner of the altar is a small stone font with its cover for storing sacred water.

Under the second baldachin, on the Gospel side [of the altar], is a crucifix about one vara in height, upon a wooden pedestal, well constructed and painted. It has a sendal of gold [silk or linen fabric] and another of lace. On its sides are the statues of Our Lady of Sorrows in a multi-layered dress adorned with fine gold galloon, and its crown of gilded $t i n$, and of St. John with tunic of coarse woolen cloth and cloak of purple taffeta, and its crown also of gilded tin. Hanging from the baldachin are purple satin curtains.

On the other side, under the third baldachin, is a canvas painting of Our Lady of Refuge about 1-1/4 varas in height, encased in a gilded frame. To its sides are the carved statues of St. Anthony, $1-1 / 4$ varas, upon a gilded pedestal, with the Christ Child; and of St. Lawrence, about three hand-spans, upon a semi-gilded and painted pedestal. Hanging from this baldachin are yellow satin curtains.

On the walls of the Presbytery are four old canvas paintings of various Saints, and on the door are cotton curtains. Also in the Presbytery are a prester chair upholstered in shag and a small table with its cotton cover upon which is an assembled statue of Our Lady of Sorrows, dressed in yellow satin, decorated with fine silver galloon, Brittany blouse [adorned] with ribbon of cloth fabric, silver dagger and crown, upon gilded and painted biers, that is used for [reciting] the rosary.

\section{Altar of the Virgin}

In the body of the Church, upon the altar on the Gospel side, is a carved semi-gilded statue of the Immaculate Conception, 1-1/2 varas in height, with silver palm and crown, golden earrings, several strands of fine and large pearls, a gold zurcillo, silver pectoral,67 two reliquaries, and several strands of coral. The statue is upon a gilded pedestal, and to its sides are two mirrors in gilded frames; it has [background] curtains of yellow satin and on the wall are four canvas paintings of various Saints.

\section{Altar of Our Father, St. Francis}

On the opposite side is another altar in which is the carved statue of our holy father, St. Francis, about a vara in height, with a crucifix in the hand, upon a gilded pedestal. On this altar are curtains of blue and white Persian silk, and four canvas paintings of various Saints.

Upon the three altars are consecrated stones, crosses, tablecloths, prayer cards, antependiums, small bells, and all that is required for the Holy Sacrifice of the Mass. On the pulpit is a baldachin 
with a crucifix. In the body of the Church are two canvas paintings of St. Ann and St. Barbara, and over one confessional is a metal engraving with gilded frame. At the entrance of the Church are two holy water fonts, one of stone and the other of copper. As adornment for the altars are several small branches with their painted and silver-stained flower pots, plus 12 copper-plated vases for flowers, In front of the Church is a cemetery enclosed by a wall of stone and mud, and in the center is a large cross upon a rock base.

\section{Baptistry}

The Baptistry is a small room below the tower, with a window, carved wooden grating, and a door with a security lock. In the center is a stone table upon which is the baptismal font which is of copper, with its cover also of copper, and dustcover of blue satin. To one side is a hand-carved cross and on the wall is a canvas painting of [St. John] the Baptist baptizing Christ. On the other side is a cupboard inlaid into the wall, with its door and key, that contains a box decorated with designs for the silver containers [for holy oils] and cotton [swabs]. It also contains three linen cloths, cowls, and a silver shell and another of metal [for pouring the baptismal water]. On the floor in a corner is a stone font with a depressed cover with holy water.

\section{Tower}

The tower is [constructed] of stone and mud, with its foundation and shaftcase of recent duration. In [the belfry] are six good bells, [ranging in weight] from eight to ten arrobas.

\section{Sacristy}

The Sacristy is a room of six varas [in area], with door and window with grating. It is plastered and has two tables, one with five drawers for ornaments, above which on the wall there is an oval canvas painting with gilded frame, of two varas in height, of Our Lady of Light, and one drawer with a Christ Child for the Nativity, and a large [drawer] for beeswax, and a small metal crucifix mounted on a well-carved wooden base. To one side, on a shelf, is the head of the statue of Our Seraphic Father [St. Francis of Assisi] that the Barbarians destroyed at San Sabá. ${ }^{68}$ The other table has six drawers and a smaller one for wax. Above it is a large painted mantel with arch and ribbed silk curtain and backing of Indianilla in which is a carved statue, 1-1/4 varas in height, of San Bernardo upon its base; another statue of the Assumption ${ }^{69}$ with silver crown, and another of St. Nicholas.

In the Sacristy is a wardrobe with doors and key in which are stored the following piezas:

\section{Sacred Vessels}

First, five chalices with their patens and [covers] and silver spoons, 
plus three extra spoons.

A medium-sized ciborium with cover of linen and sheer cloth, and a smaller one with its silver patens.

A voral with its carrying case and silver ribbon.

A silver gilded monstrance.

Four small vials for the Holy 0ils with their silver [cases], not counting three in the Baptistry.

Four sets of cruets with their silver trays.

An incensory with its boat and silver spoon.

A covering for the crucifix and silver processional candlesticks.

$$
\text { Special Vessels }
$$

Two small crystal containers with silver screw-on caps for [sacramental] wine and water.

Two small glass containers and two large metal containers and a wooden ostiary.

A small box with its key with 13 reales, three large silver rings with stones, one silver chain, two rosaries of beads, and two silk tapestries for weddings.

A new pallium 70 of blue and white Persian flowered silk, lined in ribbed silk fabric, trimmed with galloon and silk fringe; and another [pallium] of silk, lined in coarse cotton, used, with its [carrying case].

A cushion of blue embroidered velvet, new.

A tapestry of melendra, decorated with yellow ribbon, new.

Two new cotton rugs, not counting four old ones that are currently being used.

Two lengths of cotton cloth, trimmed with red ribbon, for hanging in the Presbytery.

Two large veils for covering the altars during Passion Week. ${ }^{71}$

Five missals, one unused, another slightly used, and the others [moderately used].

Five ritual books, two unused, another used, [printed in] Rome, and two [printed in] Mexico, used. 
A manual of [Christian] Doctrine in the dialect of these Indians [of the Río Grande].

One hundred and twenty-three purificators of all kinds, many of them in threadbare condition.

Fifty-five altar covers of all kinds, in good condition.

Thirty-three silk cinctures of all kinds, not counting several of cotton cord.

Ten extra double-lined corporals.

Thirty burses with their double-lined corporals of all kinds.

Five extra altar stones, two consecrated and the other three unconsecrated.

Seven extra stoles ${ }^{72}$ of various colors for the capes.

Twelve extra palls ${ }^{73}$ for the corporals and four more for the chalices and two silk kerchiefs to cover them.

Two sets of tin-plated cruets with their trays.

\section{Other Special Vessels}

Two bronze incensories with their boats and spoons.

Two holy water containers and one copper sprinkler.

A copper cross, with two vessels for blessed salt.

Six tin lanterns used when administering the Viaticum. ${ }^{74}$

A copper kettle and a tub for the washstand.

Lathe-carved wooden candlesticks with a covering for the bronze crucifix.

A child's coffin, upholstered with ribbed silk padding with its pillow and quilt of various satins and a crown of sheer lace ribbon.

A clapper used during Holy Week. 75

Thirty-one bronze candlesticks of various sizes, including the ones on the altars.

Twenty-five lathe-carved candlesticks and 79 [candlesticks] of clay, for use by the Indians on All Souls' Day. ${ }^{76}$

A chorister's lectern, a table and a box for the towels of the washstand. 
Five capes of dyed cotton and five surplices of terlinga for the altar boys.

Three narrow lengths of various satins for decorating the [octagonal] steps of the altar.

A small box with two lengths of linen, a mold and some scissors for cutting the [Communion] hosts.

An iron mold for making [Communion] hosts.

An iron hammer.

Two wooden shelves and two platforms in front of the boxes.

White Chasubles

First, a lustrine chasuble with gold flower design, trimmed with fine gold galloon, new, with antependium, maniple, 77 stole, chalice cover and matching burse for corporals.

Another [chasuble] of Persian flowered silk [with] red background and decorated with fine silver galloon and adorned with gold in the center, almost new, with antependium and other accessories.

Another of Persian silk, blue background, decorated with lace ribbon, almost new, with antependium and other accessories.

Another of damask decorated with fine silver needlepoint, almost new, with antependium and other accessories.

Two others of satin, trimmed with yellow silk galloon, new, with antependiums and other accessories.

Another of ribbed silk, decorated with double striped edging and trimmed with yellow silk galloon, new, with its accessories but without an antependium.

Another of satin, trimmed with artificial gold galloon, worn-out, with antependium and other accessories.

Another of satin, trimmed with embroidered ribbon, worn-out, with antependium and other accessories.

Another of damask, trimmed with needlepoint, with its accessories, semi-used, with a much older antependium.

Another of beautiful Chinese satin, with its accessories, worn-out, wi thout antependium.

Three new antependiums of ornamental Chinese [satin], trimmed with brilliant ribbon and silk fringe. 


\section{Red Chasubles}

A chasuble of single panel with flowers of gold and silk, trimmed with fine gold galloon, new, with antependium and other accessories. Another of flowered satin, trimmed with fine silver galloon, new, with antependium and other accessories.

Another of damask from Toledo, trimmed with silk galloon, in good condition, with antependium and accessories.

Another of striped ribbed silk, trimmed with fine silver galloon, almost new, with antependium and accessories.

Another of smooth ribbed silk, trimmed with yellow silk galloon, new, with its accessories but without an antependium.

Another of satin, trimmed with ribbon, in good condition, with antependium and accessories.

\section{Purple Chasubles}

A new chasuble of Persian flowered silk, trimmed with lace ribbon, with antependium and accessories.

Another of satin, almost new, trimmed with lace ribbon, with antependium and accessories.

Another of satin, in good condition, trimed with embroidered ribbon, with antependium and accessories.

Another of embroidered satin, worn-out, trimmed with artificial gold galloon, without antependium, with its accessories.

\section{Green Chasubles}

A chasuble of flowered satin, trimmed with fine silver needlepoint, in good condition, with antependium and accessories.

Another of Chinese satin, trimmed with smooth white ribbon, new, with antependium and accessories.

Another of satin [with] blue background, trimmed with red ribbon, old, with antependium and accessories.

\section{Black Chasubles}

Two lustrine chasubles, almost new, trimmed with white silk galloon, with its accessories [but] without antependium. 
Another of Chinese damask, used, trimmed with yellow silk galloon, with antependium and accessories.

Another of melendra, trimmed with smooth yellow ribbon, used, with antependium and accessories.

Another of velvet, used, trimmed with yellow silk revecillo, with antependium and accessories.

White Capes

A cape of blue Persian silk and satin, almost new, trimmed with artificial gold galloon.

Another of damask, worn-out, trimmed with red ribbon.

Red Cape

One of red and white satin, almost new, trimmed with fine silver galloon.

\section{Purple Cape}

One of satin, almost new, trimmed with light orange [and] fine silver [galloon].

\section{Green Cape}

One of green and blue satin, almost new, trimmed with fine gold and silver galloon.

\section{Black Capes}

One of lustrine, new, trimmed with white silk galloon, with silver clasps.

Another of melendra, almost new, trimmed with fine silver needlepoint. Another of damask, worn-out, trimmed with fine silver galloon.

\section{Various Special Vestments}

A mozetta 78 of yellow satin, new, trimmed with fine silver needlepoint, with its small antependium for distributing the Viaticum.

A silk alb, used. 
A small curtain, two hand-spans long, of striped ribbed silk, in good condition.

A new black velvet dress, trimmed with fine gold needlepoint, for [the statue of] Our Lady of Sorrows.

Another of red ribbed silk, new, trimed with fine silver needlepoint.

Another new [dress] of purple lustrine, trimmed with fine silver galloon and fringe.

Two Brittany blouses with spangles ${ }^{79}$ and eight humeral veils of sheer ribbon lace, all for Our Lady.

\section{Altar Linen}

An altar cloth of gold lamé, trimmed with fine silver galloon.

Another of single-panel fabric, trimed with embroidered ribbon and gold fringe.

Twenty-nine [altar cloths] of various satins and colors, in good condition.

\section{Protective Dust Covers}

A set of cylindrical dust covers for the cross and processional candlesticks, of yellow satin trimmed with red ribbon, in good condition.

Another only for the cross, old, trimmed with artificial gold galloon and fringe.

Another set of black satin, trimmed with artificial gold galloon and fringe, very threadbare.

White Vestments

\section{Amices}

Twenty-nine amices of all kinds with lace ribbon and ordinary ribbon, well cared for.

Albs

Four new classical albs, with good lace decorations, and another [alb], almost new.

Three classical campechanas, 80 used. 
Sixteen ordinary [aibs], well cared for.

Altar Cloths

Twenty-five altar cloths of all kinds.

Surplices

Seven used surplices.

Five lengths of linen for the communion rail, used.

Six linen tablecloths for the washstand.

\section{BOOKS OF ADMINISTRATION}

This Mission has five books in which are recorded the entries of administration.

First Book

Baptismal Entries of this

Mission of San. Bernardo Since its Foundation

It contains 721 baptismal [entries], the first of which occurred on September 15, 1703, of Juan de Dios, an adult of the Pachal [tribal] nation of Socorro; and the last [entry] of Alejandro, a child of the Pacuache, on the final day of September, 1735.

In the same Book are 401 burial entries for the same period, the first of which was of Gertrudis, an adult of the Ochan nation, on December 25, 1705; and the last [entry] of Patricio, an adult of the Pacuache nation, on March 16, 1736. The Missionary acknowledges that a fire destroyed a notebook of entries and other documents.

Second Book

Book of Baptisms of this Mission of San Bernardo

It contains 1,828 baptismal entries, including those listed in the First Book, beginning with [the name] of Ysidro, a child, son of padres gentiles 81 of the Pacuache nation, on September 24,1735 , and ending with Ygnacio, a Paezchal boy [sic], on November 15, 1772. At the end of this Book is a list of 290 confirmations. ${ }^{82}$

\section{Third Book}

Marriage Register of this Mission of San Bernardo of the Rio Grande del Norte since its Foundation

It contains 453 entries, the first of which is of Antonio Rodrigues 
of the Ocan nation, with Luisa de Santa Maria of the Patacal nation, on September 17, 1703; and the last [entry] is of Luis, [of the] Pacuache [nation], with Josefa of the Canoa nation, on October 19, 1772.

\section{Fourth Book}

\section{Burial Register of this Mission of San Bernardo}

It begins with [the entry] of Valentin of the Mirricu nation, an adult of 120 years of age [sic], on March 18, 1736; and ends with [the entry] of Ygnacio, a Pacuache child, on November 24, 1772. This Book contains 1,417 entries, including those of the other Book.

\section{Fifth Book \\ Baptismal Register of the \\ Mission of San Lorenzo de la Santa $\mathrm{Cruz}^{83}$}

It contains 114 baptismal entries, including a few of Spaniards. The first [entry] is of Pablo, a child of the Lipan [Apache] nation, on January 22, 1762, and the last [entry] is of Joseph de la Trinidad, on September 3, 1768.

Also in this Book are 28 entries of Indian burials, with a few [entries] of Spaniards, the first of which is of Juan, of the Chapamoc nation, on August 3, 1762, and the last [entry] of Juana Manuela, child and legitimate daughter of Manuel Sánchez, a soldier of [Presidio] San Sabá on March 17, 1768. In this said Book are also five entries of marriages of soldiers of the same Presidio. The first [entry was recorded] on May 18, 1766, of Francisco Xavier Pérez with Juana Rosa de Aguilar; and the last [entry was recorded] on December 28, 1777, of Feliciano Treviño with Maria Cándida Martínez.

Following the entries of the Mission of San Lorenzo, there are a few [entries] of the Mission of Nuestra Señora de la Candelaria, ${ }^{84}$ included in the same Book.

\section{ASSETS OF THE MISSION}

There is a legajo with the following documents: First, the testimony of the [Mission's] foundation, of the land grant, [and] its confirmation and boundary surveys. Another [document] of the purchase of two sitios of 1and.85 Another [document] is of the Mission's brand and mark [for livestock].

Ranch

At a distance of one league from the Mission is a house of stone and mud with three rooms, with a good roof, door and windows, for the 
vaqueros. There is a large corral for major livestock and a kiln for lime.

\section{Farm}

There is a farm of 12 banegas of corn under cultivation, [with a separate section] fenced off for beans, cotton, watermelons, squash and corn, which in the current year is ready for harvesting. It is estimated the harvest will yield, at the very least, about 800 fanegas, of which 225 will be sufficient provisions for the Pueblo [congregation]. Another 225 fanegas, stored in the granary, will be utilized beginning this date. There is an acequia extending more than 15 leagues, with its good dam. Another acequia [is located] about a quarter-league from the Mission.

\section{Indian Pueblo}

A fair-sized pueblo is developing; 40 houses of stone and mud are already constructed, with their doors, windows, roofs and kitchen gardens. [These structures] form two streets, closing off the square on one side of the Church under construction of cut stone and mortar. Already finished is the Sacristy, with a well-built arched chamber, and the Baptistry with its dome. Half of the nave ${ }^{86}$ is completed up to the cornices 87 and is ready for the arch; in some places the other half lacks three varas and in others four varas of construction to reach the cornice. On the opposite side [of the square] are the houses that have been built.

There are three kilns, one for lime, another for brick and another for large earthenware.

There are two large corrals, one of stone wall and the other of timber. There is a good orchard, with palisade fence, with a tree-lined walkway of many pecan trees and some other fruit trees.

\section{Livestock}

Cattle

This Mission has 1,204 head of cattle, from calves on up to steers, not counting some atajos 88 that were seen but could not be rounded up.

Sheep and Goats

There are 6,932 head of sheep (including 550 lambs). Of the longhaired goats there are 900 head, including 200 kid-goats. 


\section{Mares}

There are 835 mares, branded; the brood mares with their stallion jackasses, 89 and nine trainer donkeys.

Horses

There are 212 horses, including 44 colts.

Mules

There are 101 mules, young and old, including 24 tamed ones.

Oxen

Eighty yoke of oxen.

\section{Donkeys}

There are 39 jennies and jackasses.

\section{Workshops}

Near the convent, 90 this Mission has seven workshops, constructed of stone and mud, with their doors and security locks.

In the first [workshop] there are 27 plows and another [27] plowshares with yoke harness and leather strap.

In the second there are 225 fanegas of corn.

In the third there are 211 arrobas of wool, 14 sets of old pulleys and eight in good condition.

The fourth [workshop] is used as a kitchen in which there are two metates, two iron griddles and two kettles.

The fifth [workshop] is the granary with a storage capacity of 3,000 banegas of corn on the cob.

The sixth is the carpentry shop in which there are 114 cypress planks to construct other benches for the new church; 152 ordinary and 43 small boards of lumber; 203 beams, 19 crossbeams, five doors with door frames [and] nine windows with grates and frames. [In addition there are:]

A cerchon.

Eight carts, four of which are new, and poles for a new one. 
A lathe wheel and strips of wood for cutting, shaping and treating.

Two cartloads of board lengths for roofs.

In the seventh [workshop], which serves as a textile shop, there are four looms with equipment for two racks of coarse wool, four of blankets and five of muslin. [In addition there are:]

Nineteen spinning wheels.

Nine shuttles.

Sixty-eight siguenelas.

Four windlasses.

One-hundred and twenty-four spindles.

Ten new cards [for combing wool], not counting 14 which are being used.

Two Roman balances with their movable weights.

Three accurate scale pointers with their large balances and two smaller ones with their frames.

\section{CONVENT}

The living quarters of the priests consist of ten rooms which open out onto two patios. The first [room] is the kitchen in which are two kettles, one grill, one vadel, one metal mortar, one grinding stone, three copper kettles and three skillets.

In the second [room] are 60 fanegas of salt, 100 strands of chili, several small dishes and 18 grinding stones.

The third room serves as the potter's workshop in which there are a potter's wheel, some tools for the oven and wooden molds.

In the fourth [room] are a table and a box with its security lock and 125 arrobas of raw cotton and a few pounds of yarn.

In the fifth [room] there are a cot, a bed with its mattress, one carga ${ }^{91}$ of flour and three chairs.

The sixth room, which serves as living quarters, has a bed with its mattress, one bookcase, one table, three chairs and one earthen jar. In the same room are two fanegas of beans, one box of grease and another [box] of small dishes.

In the seventh [room] are one cot, the poles of a sugar mill and a cart. 
In the eighth [room] are five large kettles and one bronze stonecutter, and several old dishes.

\section{Principal Workshop}

The ninth [room] is the principal workshop in which are [the following:]

One hundred and eight pairs of shearing scissors for wool.

Four large tailor's scissors.

Thirty dozen leather shoes.

Three-hundred and eighty-three cones of piloncillo guasteco, at a rate [of exchange] of 16 to one peso.

A tercio and a half of sugar.

Four boxes of soap minus a few bars.

Five tercios of tobacco and another [tercio] already opened.

Three new iron griddles and other old ones.

Eleven adzes.

One hoof parer.

Two hacking tools [scythes].

Three lances.

Three slabs of lead.

A bullet mold.

A halberd.

Seven branding irons for the livestock.

A pruning knife.

Two arrobas of tin.

Four new leather harness gears and five of sackcloth.

Two sets of iron stirrups.

Forty small boiling cauldrons from Puebla; 17 larger ones.

Fourteen bowls, 26 small cups, 19 plates and one earthen jar. 
One tompiate of covalongas 92 and two arrobas of yerbas 93 from Puebla.

Eight new leather bags and another eight of sackcloth.

Three large door knockers.

Eight copper skillets.

Three iron spoons and skimmers.

Forty-seven copper dippers.

Four large butter dishes.

A saddle trapping and seven new, treated pieces of leather.

\section{Field Equipment}

In the same room are [the following items:]

One hundred and three plowshares, many of them worn-out.

Forty-three standard hoes and six new ones of medium size, ten shorter ones and 15 [without handles].

\section{Masonry Shop}

Forty picks [for working stone], minus various unserviceable ones.

Twenty-eight stone chisels.

Sixteen smoothing trowels.

Four plumb bobs.

One measuring stick.

Seven mason's squares, four of which are of iron.

Two poles of hicaco wood. 94

Two winches and two pulleys, one of iron.

Twenty-seven rods of all sizes.

Fifteen wedges.

Six mallets.

Two ramrods. 
Three sieves.

Six stonecutter's hammers [picks] and one trowel for removing stones.

\section{Carpentry Shop}

In said workshop are the tools of carpentry:

Seven adzes.

Thirty-four augers of all sizes.

Five carpenter's squares ....

Twenty chisels of all sizes, with four carretes.

Seven various chisels for cutting circular objects.

Five crowbars.

Four lathes.

Twenty-three framing-saws of all sizes, minus several broken ones.

Three jack-planes [for smoothing wood already planed].

Two jointing-planes and another without blade.

Three compasses of various sizes.

Three pairs of pliers.

Four hammers.

Three carpenter's planes.

Two molding strips.

Three filderetes.

A talón. 95

A gouge.

Two drawing triangles [set squares].

An auger with four drill-bits.

Two grooving planes.

A carpenter's square. 
Two wedges for splitting planks.

Two wood files and two [half-files].

Seventy-two axes.

Eight axle-boxes for carts.

Thirteen sevicas.

Twenty hinges [for doors and windows].

Eighteen locks and metal plates with their keys and nails, and another large lock and plate for the Church.

Two ceraglos with their keys.

Four dozen nails de papalote. ${ }^{96}$

Two thousand, eight hundred [nails] of various sizes and one small box of tacks of all sizes.

Seventy hinges for doors and windows.

In the said workshop are [the following:]

Six arrobas of steel and five of iron.

Eight copper pots, four copper wash basins, eight copper basinets and four syringes.

Thirty-five fanegas of new beans. ${ }^{97}$

Two arrobas of rice and two of chickpeas, and an earthen jug of 0 il.

Two grills, one chair of woven fabric, seven pairs of bits and bridles, 27 sets of saddle chains and 29 loose pieces of equipment.

Six pounds of grana. ${ }^{98}$

A small box of alum.

Two arrobas and six pounds of blue indigo.

Fifty packages of candles.

A crate of old tools.

Ma in Cell

The main cell [of the convent] is spacious and has a bedroom and a 
pantry on the other side in which are 12 [storage] boxes.

In the first [box] are two cargas of $8-1 / 2$ arrobas of polvona jina.

In another are four arrobas of chocolate of good quality, and in another is the pinole ${ }^{99}$ for the Indians' breakfast.

In the fourth is [stored] piloncillo for everyday use.

In two other boxes are six arrobas of ordinary chocolate.

In another are two tablecloths, four quilts, eight bedsheets, nine pillows and four cotton blankets, face towels and one large towel.

In the eighth [box] are:

Three rolls [bolts] of blue serge.

One roll and three varas of mican.

Three pairs of silk stockings for women.

One muffler or shawl of cotton and silk.

- Twenty varas of blue shag.

Six ordinary head scarfs.

Fourteen skeins of gold thread and three of silver thread.

Two ounces of cambric thread; a pound and a half of Moroccan thread, a pound and a half of assorted twisted silk and four ounces of assorted untwisted silk.

Ten ounces of silver fringe and one of gold.

One pound and four ounces of silk fringe.

One roll of shiny lace and six varas of another narrow [lace].

Eight varas of bonelace.

Three rolls of red ribbon.

Thirty-three varas of thick ribbon of various colors.

Twenty-nine varas of Chinese ribbon of various colors.

Half a roll of lustre ribbon.

Seven varas of yellow revecillo, and one pound of silk revecillo.

Twenty-one dozen lustre buttons. 
One vara of ribbed silk and another of [needlepoint].

Four rolls of fine, narrow Brittany linen.

Thirty and one-half varas of Rouen cloth.

Twenty-nine varas of superfine cotton cloth.

One vara of revecillo from China.

In the ninth box is the dinnerware.

The tenth [box] serves as a wardrobe for storing the Indians' clothing.

The eleventh [box] is empty.

In the twelfth box are [the following:]

Six dozen and four pairs of leather shoes.

Two dozen pairs of shoes of cord sole.

Six [table coverings].

Eighteen pounds of blue and white agave thread....

Two bolts of calico and 30 varas of remnants.

Two wicker baskets of beads, abalone shells and earrings.

Three taliguitas of paint powders.

A small box of mallets from the granary.

One pillow of Castilian rose petals.

One roll of wire screen [sieve].

One vara of Chinese ribbon.

Three gross of rosaries.

Three bottle-cases with 54 jars and three arrobas of wine.

Two English keys for the washstand.

Fourteen field knives and two table knives.

Fourteen ordinary hats.

Six candlestick rims.

Eight and three-fourths pounds of wax from the North. 
Three and one-half pounds of ordinary wax.

Six dozen large pointed knives.

Twelve metal plates from China.

A gunrack with eight escopetas, two muskets and two blunderbusses.

Three guitars and one violin.

One bag with [traveling] necessities for the sindicos, 100 with its canopy of Indianilla.

Nine small crystal glasses, one ventosa, five bowls from China and five cups.

Two large cups and seven serving plates and a China pitcher and one storage cup.

One canopy of coarse woolen cloth with its pulpit crucifix.

One copper washbasin, two large pails with their [drinking] glasses and two smaller [pails].

Two copper kettles, two pots, two shaving basins, one heater, 101 three small pots....

A razor case with two shaving razors, one whetstone, scissors and comb.

A dozen earthen jugs and two copper pitchers.

One azerruche, five sedan chairs and one bench.

Nine dinner napkins and ten spoons and [matching] forks.

Two bookcases, three manuscript volumes on the dialect of these [Mission] Indians.

Two unused account books and another of the servants' current accounts. 102

One empty barrel.

One bedstead constructed of various loose planks.

In the rear of these rooms is an inner patio that serves as a horse stable in which is a chicken coop with a few hens, a pigeon-roost and other incidentals.

One dozen saddler's needles. 
One dozen rakes....

Four paper tapes of needles of various sizes ....

Eighteen boxes of caramel candy.

Two flat irons to press [clothes].

Six candleholders for the convent cells.

Half a pound of saffron.

Two handkerchiefs and several smaller ones.

\section{ACCOUNT BOOKS}

According to the liquidation of accounts, prepared for the [formal] transfer, this Mission does not have outstanding debts. As a matter of fact, this Mission has more than one thousand [seven hundred and ninety-one] pesos and two reales owed to its credit from a few sources; none of which has been collected. Such credits have been noted in the new account book in the event it becomes possible to collect them.

CENSUS

Families

Joseph Hernández Juana, his wife

Augusto, their son

Felicia, their daughter

Baltasar

Lucia, his wife

Lucas

Juana María, his wife

Juan Diego, their son

Vicente

Rosa, his wife

Benito, their son

Rosa, their daughter

Melchor

Maria, his wife

Felipe

Bárbara, his wife

Juan, their son
Tribal Group

Papanac

Jalam

Papanac

Paco

Aguallard

Papanac

Pachal

Paco

Chaguan

Jacaof

Pacha 1

Canoa 
Families

Juan Antonio

Brigida, his wife

Pablo, their son

María Ignacia, their daughter

Luis

Josepha, his wife

Cristóval, widower

Cristóval, his son

Antonio, widower

Andrés, his son

Antonio Cano

Juana Zapópa, his wife

Isidro, orphan

Francisco

María, his wife

Magdalena, their daughter

Félis

Feliciana, his wife

Augusto, their son

Felicia, the ir daughter

Bernardino

Gertrudis, his wife

Isidro Barajas

Francisca, his wife

Gerónima, their daughter

Estévan

Margarita, his wife

Ysavel, widow

Henrique, widower

Luisa, widow

Casimiro, her son

Joseph Antonio

Martina, his wife

Joseph Luis and Mathias, their sons

Juan Andrés

María Justa, his wife

Capistrano and Pedro Joseph, their sons

Josepha, their daughter
Tribal Group

Huacasel

Paco

Pacoache

Canoa

Ocan

Paco

Canoa

Pachal

Paco

Pachache

Paco

Jacaof

Pacuache

Pacuache Jacaof

Pacuache Jacaof

Jacaof

Paco

Pacuache

Pacuache

Patacal

Patachal

Pacuache

Pacuache

Ocan 
Families

Manue 1

Agueda, his wife

Gabriel

Josepha, his wife

Francisco Bartholomé, their son

Gabriel, widower

Pedro, his son

Francisco

Rafaela, his wife

Ignacio, their son

Gertrudis, their daughter

Pedro

Estephana [his wife]

Francisco

Jacinta [his wife]

Jacinto, their son

Augustín

Maria Sebastiána, his wife

Fernando, their son

Marta, their daughter

Buena ventura

Petra, his wife

Joseph Martín, orphan

Mariano

Dorotea, his wife

Coleta, their daughter

Pablo

Rosalia, his wife

Luisa Maria, their daughter

Marcos

María Guadalupe, his wife

Andrés

Petrona, his wife

Mariano, their son

María Dolores, their daughter

Antonio

María Zapópa, his wife

Juan, their son

María Antonia, their daughter
Tribal Group

Pachal

Ocan

Pastaloc

Chaguana

Paco

Pacha 1

Paco

Catufan

Pachal

Pacuache

Catufan

Chafuanafam

Pastaloc

Chaguan

Pastaloc

Malaquito

Paco

Chaguan

Paxac

Jacaof

Payaya

Pajac

Pacuache

Pajac

Pachal

Paco 
Families

Joseph Antonio

Manuela, his wife

Jacinta, their daughter

Gerónimo

Antonia, his wife

Canegunda, their daughter

Sebastián, widower

Martin

Gertrudis, his wife

Juan Alexandro, their son

Antonio Ramón

Lucresia, his wife

Marcial, their son

Domingo, widower

Alonso

Maria, his wife

Ignacia, their daughter

Pedro [widower]

Antonio, his son

Migue1, widower

Juan Nicolás, widower

Joseph Manuel

Rosa, his wife

Asencio

María Anna, his wife

Tomás, widower

Juan Riso

María Gustina, his wife

Sinforosa, their daughter

Joseph

Josepha Antonia, his wife

Marta, their daughter

Juan Sánches

Francisca Xaviera, his wife

Arcencio, orphan

Juan Baptista

Brígida, his wife

Monica and Angela, their daughters
Tribal Group

Paco

Muncú

Pacuache

Paco

Paco

Patacal

Pacaquis

Catufan

Ocan

Ocan

Payaya

Pacuache

Pacuache

Pacuache

Pastancoya

Pastancoya

Pacuache

Aguayan

Huacasel

Aguayan

Pachal

Paco

Pachal

Patacal

Patacal

Pacuache

Pacuache

Paco

Pacha 1 
Families

Francisco

[Josefa] his wife

María Antonia, their daughter

Estévan

Faustina Ysabel, his wife

Thomás

Rosa, his wife

Reymundo, their son

Teresa, their daughter

Theodoro

Estéphana, his wife

Juan Ramón

Margarita, his wife

Pedro, their son

Cristina, their daughter

Antonio Rafael

Casimira, his wife

Bernardo

Onofra, his wife

Damasio, their son

Mathías

Petra, his wife

Gregorio, their son

Ambrosio

Antonia, his wife

Gaspár, their son

Manuel, widower

Joachin

Gertrudis, his wife

Antonio Santos

María Catarina, his wife

Juan Baptista, widower

Felipe, his son

Francisco

María Ysabel, his wife

Salvador, their son

Bernarda, widow
Tribal Group

Paco

Pastaloc

Malaquito

Paco

Pachal

Aguayam

Pachal

Paco

Huacasel

Pamuliem

Pacuache

Pacuache

Pastaloc

Juanca

Pacuache

Pacuache

Patacha 1

Pacuache

Pacuache

Pacuache

Patacal

Pastancoya

Pacuache

Pastancoya

Pacuache

Pacuache

Pacuache 
Families

Juan Roque

Maria, his wife

Marcos

Juana, his wife

Francisco, widower Andres, his son

Zeledón, widower

Buenaventura, widower

Francisco Xavier, his son

Francisco Pobre, widower

Francisco Gamán

Augusta, his wife

Joseph, their son

Thomás Antonio, their orphaned grandson

Andrés

Secilia, his wife

Miguel, Juan Capistrano and Manuel, the ir sons

Gerónimo, widower

Santiago, orphan

Domingo

Graciela, his wife

Domingo Moso

Maria, his wife

Estévan

$$
\text { Maria, his wife }
$$

Juan

María, his wife

Santiago

Antonia, his wife

Andrés

Rosa, his wife

Nicolás

$$
\text { María, his wife }
$$

Tribal Group

Aguayam

Pacuache

Pacuache

Pacuache

Pacuache

Pacuache

Muncú

Pacuache

Pacuache

Pacuache

Pacuache

Pacuache

Pacuache

Pacuache

Pacuache

Pacuache

Pacuache

Muncú

Pacuache

Pacuache

Pacuache

Pacuache

Pacuache

Pacuache

Pacuache

Huacase 1

Pacuache

Pacuache 
Families

Francisco

María de Jesús, his wife

Pedro, their son

Francisco de Asis

Lucrecia, his wife

Juan Antonio Moso

Matiana, his wife

Rosendo and Gregorio, their sons

Juan Diego

Luisa Anastacia, his wife

María Encarnación, their daughter

Luisa, widow

Nicolás Barajas, widower Juan Francisco, his son

Silvestre

Felipa, his wife

Viviana, their daughter

Santiago, widower

$$
\text { Isidro, his son }
$$

Bárbara, widow

Cristóval

Serafina, his wife

Antonio de Padua, widower

Félis

Estéfana, his wife

Carlos, widower

Mariano Antonio, his son.

María Candelaria and María Rosa, $h$ is daughters
Tribal Group

Pacuache

Pacuache

Pacuache

Pacuache

Huacase1

Pacuache

Pacuache

Pacuache

Pacuache

Pacuache

Aguayan

Pachal

Pacuache

Pacuache

Pastaloc

Aguayan

Aguayan

Canoa

Pastaloc

Payaya

Pacuache

Juan Baptista Brígido, widower

Al1 of the above mentioned Christian Indians, who are of age, go to confession and receive communion annually. They all have their new clothes which is the custom [at the Mission] to distribute to them each year, such as blouses, petticoats, shawls, undergarments of coarse cotton and flannel, jackets and blankets, hats, large pointed knives, combs and other incidentals. Many of them have cloaks and long coats, and all have shoes and stockings and kitchen utensils. 
Accordingly, they seem to be well instructed in Christian doctrine and in vocational crafts. The Ministers are required to devote great vigilance to their instruction in Christianity and political responsibility. Nothwithstanding the admiration for such abundance [in material assets], the wastefulness of the Indians is quite natural.

In the preceding manner the Reverend Father President, Fray Diego Ximénez, in behalf of his College, transferred to the Reverend Father Commissary, in behalf of his Province, everything that he found which is listed [in the inventory]. At this point the Reverend Father Commissary accepted the administration and assets of the Mission, in the temporal as in the spiritual, in the manner prescribed by the foregoing. 


\section{NOTES}

1 As early as 1732, Vicente Rodríguez, an inhabitant of Monclova, Coahuila, arrived at the Rio Grande for frontier service with the governor of Texas, Juan Antonio de Busti1lo y Ceballos. In 1744, Vicente's elder brother, Manuel, became commandant of Presidio San Juan Bautista del Rio Grande. In the autumn of that year, Lieutenant Vicente Rodríguez joined his brother at the Rio Grande, from where periodically he led punitive expeditions against Indian marauders. When Manuel died in 1772, after 29 years of leadership at the same outpost, Vicente assumed command of the presidio on an interim basis. See Robert S. Weddle, San Juan Bautista: Gateway to Spanish Texas (Austin: University of Texas Press, 1968).

2 Father Antonio Llinás, O.F.M., founded the Apostolic College of Santa Cruz in Querétaro in 1683 to train Franciscan missionaries for frontier service. Santa Cruz became the model for a system of apostolic colleges throughout Spanish America. See Michael B. McCloskey, The Formative Years of the Missionary College of Santa Cruz of Querétaro, 1683-1733 (Washington, D.C.: Academy of American Franciscan History, 1955).

3 The Franciscans began their missionary work in Jalisco, in the western corridor of New Spain, shortly after their arrival in the 16th century. So extensive were their endeavors that in 1606 they organized the territory into the separate ecclesiastical Province of Santiago de Jalisco. See Marion A. Habig, "The Franciscan Provinces of Spanish North America," The Americas 1, No. 3 (January 1945).

4 Jacobo Ugarte y Loyola arrived in New Spain in 1769 to assume the military governorship of Coahuila. Ultimately he became Commandant General of the Interior Provinces, an administrative reorganization initiated by the Bourbon Reformers in 1776. Ugarte's service record included 45 years in the royal forces, of which 15 reflected duty performed in the northern frontier of the viceroyalty. As governor of Coahuila, Ugarte demonstrated independence of judgment and initiative, characteristics of leadership that retarded rapid advancement in grade. See Max L. Moorhead, The Apache Frontier: Jacobo Ugarte and Spanish-Indian Relations in Northern New Spain, 1769-1791 (Norman: University of Oklahoma Press, 1968).

5 Antonio María de Bucareli y Ursua, forty-sixth Viceroy of New Spain, enjoyed the good fortune of governing a long period, from September 23, 1771, unti1 his death on April 9, 1779. Among his notable accomplishments in office were reinforcing coastal defenses, constructing hospitals for indigent patients, completing the drainage project in Mexico City and inaugurating a beautification program of parks and boulevards (Alameda Central) in the viceregal capital. See Gobernantes de México: 1325-1911 (Mexico City: Revista Artes de México, 1960).

6 A linear measurement, approximately 33 inches.

7 In the Roman Catholic Church, a presbytery is also called a rectory.

8 The left side of the church, facing the main altar from the front entrance. 
9 The right side of the church, facing the main altar from the front entrance.

10 Chintz, a dyed or stained calico imported from India.

11 Probably the center of the altar.

12 Consecrated oil, used in various rites such as baptism.

13 Approximately one foot square and one inch thick--generally of marble--upon which the celebrant places the Eucharist and chalice. Altar stones are consecrated by a bishop; engraved on the under-surface are five crosses depicting the five wounds of Christ.

14 An arroba was a unit of weight equivalent to 25 pounds.

15 A room in a church in which sacred vessels, vestments, etc., are stored.

16 In the colonial period, an alhaja connoted a valuable ornament or a fine piece of furniture, highly prized.

17 A repository or receptacle for a relic or relics.

18 Altar boys in this context. In a more technical sense, an acolyte is a member of the highest rank of the four minor orders, the lowest rank being ostiary.

19 A chalice is for the wine of the Eucharist.

20 A metal plate on which the bread is placed in the celebration of the Eucharist.

21 A vessel containing consecrated wafers for the Eucharist.

22 A container in which incense is burned in religious ceremonies.

23 A dish resembling a boat in which incense is kept.

24 A vessel, especially for containing oil.

25 A box or vessel in which the reserved Eucharist or Host is kept when traveling.

26 Among Spanish-speaking Catholics, it was customary in the wedding ceremony for the groom to present coins (arras) to the bride as a symbol of sharing his worldly possessions, in addition to the exchange of rings.

27 An oblong vestment, usually of white linen, for wearing under the alb about the neck and shoulders.

28 A long-sleeved linen vestment, worn chiefly by priests.

29 A loose fitting, broad-sleeved white vestment worn over the cassock or habit.

30 Cloths used in the Mass for cleaning or ritual. 
31 A fine altar cloth, usually of linen, on which the consecrated elements are placed during the Eucharist.

32 A sleeveless outer vestment worn by the celebrant at Mass.

33 Full-length cape, open in front and secured with a clasp; in addition, it had an escutcheon decorating the outer surface in the back. The cape was worn for solemn occasions.

34 The decoration of the front of the altar, such as a panel or a covering.

35 A fanega was a type of arid measure equal to 2.58 bushels.

36 An almud, another type of arid measure, was the equivalent of 6.88 dry quarts.

37 In this context, a fanega connoted an agrarian land measure of 8.81 acres under cultivation.

38 A league was a linear measure equivalent to 2.60 miles.

39 An archival term signifying a bundle of documents or files.

40 The royal patronage (patronato real), promulgated by Pope Julian II in 1508, delineated the special relationship of the church and state in Spain and the New World colonies. The patronato real remained in effect throughout the entire colonial period.

41 A leaf in a collection of documents; technically a foja was not the same as a printed page in a book.

42 In this context, a folio probably meant a particular section or heading.

43 Párvulo was not a common Spanish surname; literally it meant a small child. As used in this context, it probably referred to a boy whose Christian name was Pedro. Párvulo (or the feminine párvula) usually identified Indian children.

44 An escopeta was an early model shotgun.

45 An azumbre was a liquid measure equivalent to four pints.

46 In this context, ventosas were suction glasses.

47 The term de la tierra, in all probability, referred to low quality or cost, rather than to any ingredients of clay used in the construction of the candlesticks.

48 A hard, brown-sugar cone.

49 Chocolate beaters, used to create a foam in the hot beverage before serving.

50 A cure-a11, panacea. 
51 Pods of the drumstick tree, used medicinally as a laxative.

52 Tercio was a local unit of measure frequently used in the Borderlands. Usually it connoted a bale or bundle of sugar or fruit; sometimes it was used to inventory tobacco. In practical terms, a tercio was one-third of a hundredweight bale or bundle.

53 Used medicinally as a fast-healing caustic substance. Weavers also used alum for dyeing wool. The alum mordant rendered the dye more permanent and resistant to fading. See Juanita Jarami110, "Rio Grande Weaving: A Continuing Tradition," in Hispanic Crafts of the Southwest, ed. by William Wroth (Colorado Springs: The Taylor Museum of the Colorado Springs Fine Arts Center, 1977).

Given the frequent references in the inventory to painted surfaces and picture frames, it was probably used as an oil paint pigment.

Bright-red, water-insoluble pigment.

White lead, used chiefly in paints and putty.

The quality of the container suggests it was used medicinally for ulcers.

58 The area of processing was either Nueva Vizcaya (later called Chihuahua) or New Mexico.

59 When the tribal identity of the wife differed from that of the husband, the offspring of the union acquired their mother's cultural affinity. This social phenomenon suggests two tentative conclusions: Either the census taker found it expedient to use this classification or it was a subtle acknowledgement of the existence of a matriarchal system among mission Indians that the friars permitted to continue until the acculturation process had been completed and other forms of identification took precedence, such as gente de razón or vecino.

60 Training in pueblo government enabled the Indian participants to become acquainted with Spanish civil responsibilities. The principal offices which rotated periodically were governor, alcalde and fiscal.

61 Mestizo was not a tribal group. It was a distinct social classification to identify the offspring of the union of a Spaniard and an Indian woman. Conceivably, it also meant the child of a Spanish woman and an Indian male. Since the census taker labeled Aguilera's family as squatters, most likely they immigrated northward to the mission and became integrated among the Indian families. If the squatter or mestizo family is not included in the headcount of married families, the final tally corresponds with the total cited in the vital statistics at the conclusion of the census.

62 Persons undergoing instruction in the rudiments of Christianity; neophytes.

63 The mission residents evidently recognized this Indian woman for her relationship as the wife (or widow) of a native endowed with leadership skills or for her own dominant social capabilities. 
64 Apparently the census taker had his own system of counting. Only the totals for the categories of married families, widows and widowers and catechumens compare correctly with the vital statistics at the conclusion of the census.

65 The rules of the Franciscan friars of Querétaro prohibited the missionaries from personally administering financial affairs. For this reason the college employed a layman--called sindico apostólico (apostolic syndic)--to supervise these temporal responsibilities of mission administration.

66 This bell is rung during the celebration of the Mass to call attention to the more solemn parts of the liturgy.

67 A cross worn by bishops on the breast.

68 Comanche aggressors, in March of 1758, raided the Mission of Santa Cruz de San Sabá, founded by Fray Alonso Giraldo de los Terreros in the north-central hill country of Texas. Among the fatalities was Fray Terreros, former president of the Rio Grande missions. See Robert S. Weddle, The San Sabá Mission: Spanish Pivot in Texas (Austin: University of Texas Press, 1964); Paul D. Nathan (trans.) and Lesley Byrd Simpson (ed.). The San Sabá Mission: A Documentary Account of the Founding and Destruction of San Sabá Mission (San Francisco: John Howell Books, 1959).

69 The Assumption of the Virgin Mary, a feast traditionally observed on August 15.

70 A large rectangular mantle, consisting of a narrow band resting on the shoulders, with a lappet in front and back; usually worn as an insignia of office by archbishops and bishops. In the context of the inventory, a pallium could also be a cloak.

71 The week before Holy Week, beginning with Passion Sunday.

72 An ecclesiastical vestment worn over the shoulders by priests, consisting of a narrow strip of silk or another fabric.

73 A linen cloth or a square-covered piece of cardboard used to cover a chalice during the sacrifice of the Mass.

74 The Eucharist or Holy Communion as given to the sick or persons in danger of death. The six lanterns, with candles inside, were part of the processional ceremony.

75 During the solemnity of Holy Week a wooden clapper is used in lieu of the liturgical bell.

76 November 2. The Indians carried the candlesticks in a procession to the cemetery where they recited prayers for the deceased.

77 An ecclesiastical vestment, consisting of an ornamental band worn by the celebrant on the left arm near the wrist. 
78 A short hooded cape, usually worn by a bishop, that can be buttoned over the breast.

79 Small, thin, often circular, pieces of glittering metal or other material.

80 Probably made of a fabric woven in Campeche, a city on the west coast of the Yucatán peninsula.

81 Native parents who have not been converted.

82 A solemn ceremony in which the rite of confirmation is administered to a baptized person by which he/she is admitted to full communion with the Church. In colonial Mexico, because there were so few bishops to administer this sacrament, infant children were baptized and then confirmed in quick succession.

83 Located near the headwaters of the upper Nueces River in Texas.

84 Collectively, Mission Nuestra Señora de la Candelaria and Mission San Lorènzo de la Santa Cruz were known as El Cañón Missions. Prior to the renowned inspection by the Marqués de Rubí in 1767, the friars of Querétaro already had abandoned Mission N. S. de la Candelaria.

85 A sitio was an area measurement of approximately 4,428 acres. According to the 1772 inventory, Mission San Bernardo purchased 8,856 additional acres.

86 The principal longitudinal area of the church.

87 The uppermost section of a wall.

88 An archaic expression connoting strays.

89 For breeding hybrid mules, an important industry on the frontier.

90 Actually, convent and convento are not equivalent terms in English and Spanish. In English, a convent signifies a monastic community of nuns or monks who observe a conventual 1 ife style, isolated from the temporal world. In contrast, the term convento, used in colonial New Spain, connoted the living quarters and adjacent workshops of the resident friars. Irrespective of a mission's geographic isolation, the Franciscan friars performed their duties in a temporal environment and not in a monastery. As a matter of convenience for the reader, convento has been translated as convent in this study.

91 As a unit of weight, a carga varied widely, depending on the comodity being purchased or sold. The carga of flour in the inventory probably weighed about 300 pounds.

92 A plant of the Lauraceae family used as a substitute for quinine.

93 Most likely herbs and condiments.

94 West Indian tree of the rosaceous family.

95 Molding. 
96 In colonial Mexico, papalote signified kite. Hence, the nails, if used in the construction of kites, were probably very small and thin.

97 Recently harvested and shelled.

98 Cochineal, used in dyeing fabrics.

99 Sweetened cereal powder, sometimes mixed with chocolate.

100 Since the Franciscan rules prohibited the friars from administering funds, the apostolic colleges hired a lay syndic to transact financial affairs for the missionaries. Such responsibilities assuredly included travel to the frontier missions to distribute supplies. The canopy described in the inventory perhaps was an umbrella for protection from rain or sun.

101 More likely a room heater rather than a bed warmer.

102 After seven decades of operation, the Río Grande missions achieved a comparatively high level of material culture which enabled the frontier friars, obviously with permission of the college administration, to employ servants to perform basic everyday chores at the convento. Although the records are not clear on this point, the servants in all probability were civilian settlers who resided at the nearby Presidio San Juan Bautista del Río Grande. 